\title{
On the Origins of le Droit Moral: How Non-Economic Rights Came to be Protected in French IP Law
}

Susan P. Liemer

Follow this and additional works at: https://digitalcommons.law.uga.edu/jipl

Part of the Intellectual Property Law Commons, and the International Law Commons

\section{Recommended Citation}

Susan P. Liemer, On the Origins of le Droit Moral: How Non-Economic Rights Came to be Protected in French IP Law, 19 J. INTELL. PROP. L. 65 (2011).

Available at: https://digitalcommons.law.uga.edu/jipl/vol19/iss1/4

This Article is brought to you for free and open access by Digital Commons @ University of Georgia School of Law. It has been accepted for inclusion in Journal of Intellectual Property Law by an authorized editor of Digital Commons @ University of Georgia School of Law. Please share how you have benefited from this access For more information, please contact tstriepe@uga.edu. 


\title{
ON THE ORIGINS OF LE DROIT MORAL: HOW NON-ECONOMIC RIGHTS CAME TO BE PROTECTED IN FRENCH IP LAW
}

\author{
Susan P. Liemer
}

\section{TABLE OF CONTENTS}

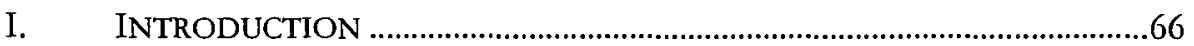

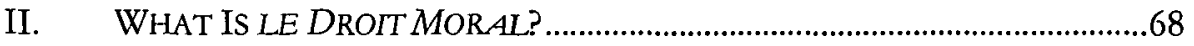

III. WHERE WERE THE EARLIEST ORIGINS OF LE DROIT MORAL? ...........72

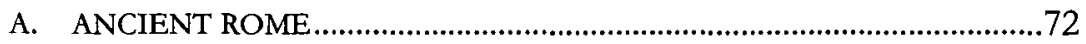

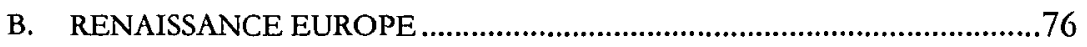

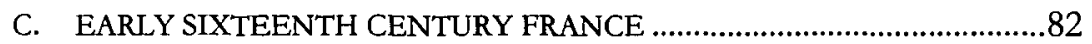

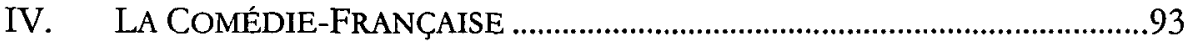

V. THE REVOLUTIONARY STATUTES AND EARLIEST MODERN

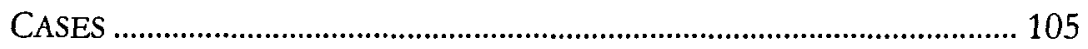

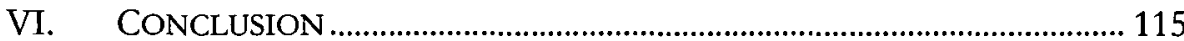

* Associate Professor \& Director of Lawyering Skills at Southern Illinois University School of Law; B.A., Princeton University; J.D., University of Virginia School of Law. I would like to thank Professor Emerita Laurel Wendt for her invaluable library assistance. I thank Professors Hillary Burgess, Dan Weddle, Mike Murray, and Amy Vorenberg for reading an early draft. 
First, a light noise, skimming the ground like a swallow before the storm, ..., it murmurs and takes off, and sows the poisoned arrow as it runs. Some mouth picks it up, and ..., glides it deftly into your ear. The harm is done; it sprouts, creeps, travels on, and ... from mouth to mouth it goes ...; then, all at once,..., you see slander rising, hissing, swelling, growing before your eyes; it leaps forward, extends its flight, whirls, envelops, tears, drags, bursts and thunders, and becomes,..., a general cry, a public crescendo, a universal chorus of hatred and condemnation. ...

\section{INTRODUCTION}

Shortly after the 2009 release of the Guitar Hero 5 video game, Courtney Love, the widow of rock star Kurt Cobain, threatened to sue Activision, the game's publisher. Love disapproved of the way Cobain's image was used as an avatar in the game. Within the game, the avatar could be unlocked, allowing gamers to make the Cobain avatar strike all kinds of poses and sing in ways that seemed "disrespectful to his legacy." 2 According to Activision, Love had signed the necessary licenses and releases. ${ }^{3}$ Under United States law, there was little she could do to protect Cobain's rock star reputation and prevent uncharacteristic behavior and music from being attributed to him.

In the quote that prefaces this Article, the eighteenth century playwright Beaumarchais has a character complain about a similar attack on that character's reputation. ${ }^{4}$ Through the medium of the play, you can hear the voice of the

1 Pierre A. Caron de Beaumarchais, Le Barbier de SÉville act 2, sc. 8 (1775) (trans. the author) ("D'abord un léger bruit, rasant le sol comme birondelle avant l'orage, ..., murmure et file, et sème en courant le trait empoisonné. Telle bouche le receuille, et..., vous le glisse en l'oreille adroitement. Le mal et fait; il germe, il rampe, il cbemine, et ... de bouche en bouche il va ...; puis tout à coup, ..., vous voyez calomnie se dresser, siffler, s'enfler, grandir à vue d'oeil. Elle s'élance, étend son vol, tourbillonne, enveloppe, arrache, entraîne, éclate et tonne, et devient,...., un cri général, un crescendo public, un chorus universel de baine et de proscription."). Rossini turned this play into the famous comic opera, The Barber of Seville (Il Barbiere di Siviglia).

2 James Montgomery, Nirvana Bandmates Dismayed' by Kurt Cobain's Image in 'Guitar Hero 5,' MTV NEws (Sept. 11, 2009, 1:19 PM), http://www.mtv.com/news/articles/1621271/nirvana-re spond-kurt-cobain-guitar-hero.jhtml; see also Dave Itzkoff, No Apologies in Dispute over Game with Cobain, N.Y. Times, Sept. 14, 2009, at C2.

3 See Sean Michaels, Courtney Love to sue over Kurt Cobain Guitar Hero appearance, GUARDIAN.CO.UK (Sept. 10, 2009, 11:54 AM), http://www.guardian.co.uk/music/2009/sep/10/ courtney-love-kurt-cobain (quoting the publisher saying "it was 'great to work with' "Love); Shirley Halperin, Kurt Cobain Joins "Guitar Her 5": How Ninvana Came to the Game, Rolling STONE (Aug. 27, 2009, 2:04 PM), http://www.rollingstone.com/music/news/kurt-cobain-joins-guitar-he ro-5-how-nirvana-came-to-the-game-20090827 (stating "securing the proper approvals was no small feat").

4 Beaumarchais, supra note 1. 
playwright himself, commenting on attacks on his own reputation and honor. $\mathrm{He}$ is not only referring to garden variety torts, like slander, which the common law recognizes. $\mathrm{He}$ is referring to harms against which artists in many media now receive protection in France and other civil law countries, through intellectual property laws known as le droit moral.

The received wisdom states that the development of le droit moral awaited the theoretical and philosophical underpinnings of Hegel, Kant, and various modern French theorists. ${ }^{5}$ In this Article, I disagree with that received wisdom. I analyzed the history of early French intellectual property law to see how and why le droit moral developed in France before spreading to much of the civil law world. ${ }^{6}$ I looked for the legal, social, and historical influences on the development of intellectual property law in France that led to le droit moral. I found such influences in some surprising places.

In Part II of this Article, I explain some basic definitions and parameters for my study. Starting with the earliest possible influences, in Part III, I describe aspects of the ancient Roman law that addressed some of the same concerns as le droit moral. As Part III continues, I analyze how the beginning of early legal roots of intellectual property law in the late Middle Ages and Renaissance addressed and made possible the protection of non-economic values, as new technologies and new views about creative work developed.

Part IV moves forward to the early modern period, where I examine the special role of the playwrights of the Comédie-Française in the development of French intellectual property and intellectual property law. I argue that the unique situation of these playwrights influenced the rules regulating French

5 See, e.g., Edward J. Damich, The Right of Personality: A Common-Law Basis for the Protection of the Moral Rights of Authors, 23 GA. L. REv. 1, 26-30 (1988) (reviewing the German philosophy and competing French scholarship on monism and dualism said to underlie te droit moral); Linda J. Lacy, Of Bread and Roses and Copyrights, 1989 DuKE L.J. 1532, 1541-42 (referring to "intellectual property theorists" who contended the "personhood theory of property" of Hegel and Kant supported moral rights theory); Cyrill P. Rigamont, The Conceptual Transformation of Moral Rights, 55 AM. J. COMP. L. 67, 92-111 (2007) (reviewing the late eighteenth and early nineteenth century droit moral theories); Cheryl Swack, Safeguarding Artistic Creation and the Cultural Heritage: $A$ Comparison of Droit Moral Between France and the United States, 22 COLUM.-VLA J.L. \& ARTS 361, 370 (1998) ("Droit moral principally evolved out of the eighteenth and nineteenth century German philosophies of ... Kant ... and ... Hegel...."); David Vaver, Moral Rights Yesterday, Today and Tomormow, 7 INT'L J.L. \& INFO. TECH. 270, 276 (1999) (assuming "the theorizing of Kant and Hegel" as central to te droit moral); of. DAVID SAUNDERS, AUTHORSHIP AND COPYRIGHT 95-102 (1992) (criticizing as revisionist history previous leading scholars' accounts of le droit moral).

6 See, e.g., Benjamin Davidson, Lost in Translation: Distinguishing Between French and AngloAmerican Natural Rights in Literary Property, and How Dastar Proves that the Difference Still Matters, 38 CORNELL INT'L L.J. 583, 612 (2005) ("Napoleonic expansion in the early nineteenth century brought authors' rights to Belgium and Holland, and influenced legal developments in Italy and Switzerland ....?'. 
intellectual property in the early modern period in particular ways that helped le droit moral develop.

Part $\mathrm{V}$ notes the earliest modern cases in which French judges provided the protections that would later come to be known as le droit moral. Part $\mathrm{V}$ also considers how it was possible for judicial decisions to develop this area of the law in France, barely a generation after the French Revolution and Napoleon established France as the ultimate code country. Finally, Part VI offers some suggestions as to the lessons learned from this history.

Note that throughout this Article, I use the word "author" as the French intellectual property law uses "auteur," to refer to all manner of literary, visual, and performing artists. ${ }^{7}$ When referring specifically to writers, I will use terms like "writers" or "literary artists," so as not to confuse the more general and more specific denominations.

\section{WHAT IS LE DROIT MORAL?}

As in the United States, the right to own and use intellectual property in France is not monolithic. Just as the copyright laws in the United States recognize a bundle of rights, ${ }^{8}$ so too do the analogous French laws. The French system, however, can be said to recognize two related bundles of rights, ${ }^{9}$ with one bundle primarily protecting economic interests in creative work, droits patrimoniaux, ${ }^{10}$ and one bundle primarily protecting other, non-economic values

7 The French term for "copyright" is le droit d'auteur, literally "the author's right." The term came into use when writers first gained rights in their creative work, infra p. 91, and now refers to rights of creators of all types of creative work. See CODE DE LA PROPRIÉTÉ INTELIECTUELLE, art. L111-1 (Fr.) (consolidated June 20, 2008) (granting a property right to "IV'auteur d'une oeuvre de l'esprit," the author of a creative work); id. art. L112-1 (establishing protection for the rights of authors of all creative works, whatever their genre, form, merit, or purpose: "Les dispositions $d u$ présent code protigent les droits des auteurs sur toutes les oeuvres de l'esprit, quels qu'en soient le genre, la forme d'expression, le mérite ou la destination."); id. art. L112-2 (listing the wide range of works protected, from sermons to software to furniture fabrics). The United States copyright statute also uses the term "author" in the more generic sense, but defines the term "author" only indirectly by defining "works of authorship." 17 U.S.C. $\$ 102$ (2006) (providing a more limited list of protected works).

8 See 17 U.S.C. $\ 106$ (2006) (granting the right to reproduce, perform, and display a copyrighted work, prepare derivative works based upon it, and distribute copies of it).

9 See Davidson, supra note 6, at 585 ("French authors have long been accustomed to defending not only their positive law economic rights, but an entirely separate category of 'moral rights' (or droit moral) as well."). Note that the Universal Declaration of Human Rights also refers to two types of related rights in creative work: "Everyone has the right to protection of the moral and material interests resulting from any ... literary or artistic production of which he is the author." Universal Declaration of Human Rights, G.A. Res. 217(III)A, U.N. Doc. A/RES/217(III) (Dec. 10, 1948).

10 CODE DE LA PROPRIÉTÉ INTELLECTUELLE arts. L122-1 - L122-12 (Fr.) (consolidated June 20, 2008). 
in the work, droits moraux. ${ }^{11}$ And so le droit moral is the part of the French intellectual property law that focuses primarily on non-economic rights in creative work. ${ }^{12}$ The term le droit moral has usually been translated into English as "moral rights," only a rough approximation of the French meaning. ${ }^{13}$

On March 11, 1957, the French national legislature enacted their first statute to protect the non-economic interests in creative work. ${ }^{14}$ In doing so, it simply codified the bundle of non-economic rights that had been developing via French judicial decisions for at least 130 years. ${ }^{15}$ These rights were wellestablished in France before 1957, ${ }^{16}$ and indeed the type of hard case that can make bad law ${ }^{17}$ was the catalyst for legislative action to preserve them.

In France, the bundle of rights known as le droit moral consists of four basic . rights: ${ }^{18}$

11 CODE DE LA PROPRIÉtÉ INTELLECTUELLE art. L121-1 - L121-9 (Fr.) (consolidated June 20, 2008). See generally Susan P. Liemer, Understanding Artists Moral Rights: A Primer, 7 B.U. PUB. INT. L.J. 41 (1998).

12 See Davidson, supra note 6, at 586-88 (describing le droit moral as "codifications of idiosyncratic French conceptions of natural rights"). But see Robert C. Bird, Moral Rights: Diagnosis and Rebabilitation, 46 AM. Bus. L.J. 407 (2009), available at http://ssrn.com/abstract=1033021 (asserting that moral rights are compatible with and supportive of economic interests in creative work); Liemer, supra note 11, at 44 (acknowledging the interplay between le droit moral and economic rights).

13 See Liemer, supra note 11, at $41-42$ (explaining the term connotes a right based on ethical behavior and societal interest, not morality per se). The lack of a direct, accurate way to translate this term may be a factor delaying acceptance of these rights in the United States. See, e.g., Damich, supra note 5, at 6 (arguing that the phrase "personal rights" more accurately translates and avoids misleading connotations of "moral rights").

14 Loi 57-298 du 11 mars 1957 sur la propriété littéraire et artistique [Law 57-298 of March 11, 1957 on Literary and Artistic Property], Journal OfFICIEL DE LA RÉPUBLIQUE FranÇAISE 0.O.] [OFFICIAL GAZETTE OF FRANCE], March 14, 1957, p. 2723 [hereinafter Law 57-298].

15 See infra pp. 112-14; Davidson, supra note 6, at 586 ("From at least the French Revolution, and arguably dating back to the sixteenth century, the French state has consistently protected authors' reputations,.... "); William Strauss, The Moral Right of the Autbor, 4 AM. J. COMP. L. 506, 506 (1955) ("The French ... courts have pioneered the application of the doctrine.").

16 For example, in 1936 a French court was able to assert, "the special nature and character of the author's right over his work ... have led case-law to recognize a whole series of rights for the author which no legislative provision or edict has enshrined." Canal $x$. Jamin, Trib. Seine, Apr. 1, 1936, Dalloz 69 (note Nast) (confirmed, Feb. 23, 1938, Dalloz 186) (quoted in Alain Strowel, Droit d'auteur and Copyright: Between History and Nature, in OF AUTHORS AND ORIGINS: EsSAYS ON Copyright LAw 235, 248 (Brad Sherman \& Alain Strowel eds., 1994)).

17 Bowers c. Bonnard, Trib. Civ. Seine, Oct. 10, 1951, D. Jur. 1952, 390, note Desbois (reconciling both the right of disclosure and the French marital community property scheme to deny an artist's wife's heirs' claim to the artist's unfinished paintings when he died).

18 Exactly what is in the bundle has changed over time. For example, resale royalties, once considered among the droits moraux, see Law 57-298, supra note 14, art. 42 (original codification); Berne Convention for the Protection of Literary and Artistic Works, art. 14, Sept. 9, 1886, revised July 24, 1971, 828 U.N.T.S. 221 [hereinafter Berne Convention]; Liemer, supra note 11, at 55-56; 

French term
1. le droit à la paternité
2. Le droit au respect de l'oeuvre
3. le droit de divulgation
4. Le droit de repentir or de retrait

\author{
English translation \\ the right of attribution \\ the right of integrity \\ the right of disclosure \\ the right of withdrawal
}

In brief, the right of attribution allows an author's name to be properly associated with the author's creative work. ${ }^{19}$ The right of integrity allows an author to maintain creative control over a work after selling it, so that a new owner can only modify the work with permission from the person who created it. ${ }^{20}$ The right of disclosure gives the author exclusive authority to determine

Liliane De Pierredon-Fawcett, The Droit De Suite in Literary and Artistic Property: A Comparattve LAw STUDY (John M. Kemochan ed., 1991), are now placed among the droits patrimoniaux. See Code de la Propriété Intellectuelle art. L122-8 (Fr.) (granting visual artists the right to resale royalties when a professional dealer is involved in the sale: "Les auteurs d'oeuvres originales graphiques et plastiques. . . bénéficient d'un droit de suite, . . lorsque intervient . . . un professionnel du marcbé de l'art."). In the United States, resale royalty rights are granted only in California, and only for visual arts. California Art Preservation Act, Cal. Civ. Code $\int 987$ (2005). Throughout the United States royalties for the literary arts are handled via private publishing contracts, and royalties for the performing arts are handled by contracts with various union and private organizations, like ASCAP and BMI.

12 Code de la propriété intellectuelle art. L121-1 (Fr.) (granting an author the right to have his name and his position as the author respected: "L'auteur jouit du droit au respect de son nom, [et] de sa qualité...."). Law 57-298, supra note 14; Berne Convention, supra note 18, art. 6, bis 1 (modeled on the French right of attribution, granting "[i]ndependently of the author's economic rights, and even after the transfer of the said rights, the author shall have the right to claim authorship of the work. ..."); Liemer, supra note 11, at 47-49. The analogous law in the United States is of recent vintage and not as well-developed. 17 U.S.C. $\int 106 \mathrm{~A}(\mathrm{a})(1)$ (2006) (granting only painters, sculptors, and art photographers a limited right to claim authorship of their respective works and prevent their names from being used on works that they did not create).

20 Code de la proprièté intellectuelle art. L121-1 (Fr.) (granting an author a right to have the integrity of his work respected: "L'auteur jouit du droit au respect. . . de son oeuvre."); see also Law 57 298, supra note 14; Buffet c. Fersing, Cour d'appel de Paris [CA] [regional court of appeal] Paris, May 30, 1962, D. Jur. 1962, 570, note Desbois, aff'd Cour de cassation [Cass.] [supreme court for judicial matters] Paris, 1e civ., July 6, 1965, Gaz. Pal. 1965, 2, 126 (Fr.) (ordering an auctioneer, who had dismantled painted refrigerator panels to sell separately, to put the refrigerator back together, in the original form as the artist had completed it); Huston c. La Cinq, Cour de cassation [Cass.] [supreme court for judicial matters] le civ., May 28, 1991, JCP 1991 II, 21731 (Fr.) (enjoining the showing of Ted Turner's colorized version of John Huston's movie, The Asphalt Jungle); Berne Convention, supra note 18, art. 6 bis 1 (granting the author "[i]ndependently of the author's economic rights, and even after the transfer of the said rights, ... the right ... to object to any distortion, mutilation or other modification of, ... the said work, which would be prejudicial to his honor or reputation"); Thomas P. Heide, The Moral Right of Integrity and the Global Information Infrastructure: Time for a New Appraacb?, 2 U.C. DAVIS J. INT'L L. \& POL'Y 211, 229-51 (1996) (providing an overview of the right of integrity in the United States, United Kingdom, Germany, and France); Liemer, supra note 11, at 50-52; John Henry Merryman, The Refrigerator of Bermard Buffet, 27 HASTINGS L.J. 1023 (1976). Here too the analogous law in the United States is 
when a work is finished and may be disclosed to the public.21 And conversely, the right of withdrawal allows an author to take a work back, withdrawing it from the world.22

An important element of le droit moral is the consideration it requires for the creative decisions of the author, ${ }^{23}$ essentially protecting the relationship between the author and the work. ${ }^{24}$ The French judicial decisions, ${ }^{25}$ the 122 -year-old Berne convention, ${ }^{26}$ the 1957 French legislation, ${ }^{27}$ and even the narrow United States law on point ${ }^{28}$ all guard the "honor and reputation" of the author. ${ }^{29}$ How

not well-developed. 17 U.S.C. $\$ 106 \mathrm{~A}$ (a)(3) (2006) (granting only painters, sculptors, and art photographers a limited right to prevent modification or destruction of their work).

21 Code de la propriété intellectuelle art. L121-2 (Fr.) (granting an author the sole right to disclose a work: "L'auteur a seul le droit de divulguer son oeuvre. ... [I]l détermine le procédé de divulgation et fixe les conditions de celle-ci.'); see also Law 57-298, supra note 14, art. 52.; Eden c. Whistler, Cour d'appel [CA] [regional court of appeal] Paris, 1898, D.P. II 465, aff'd Court de cassation [Cass.] [supreme court for judicial matters] 1900, D.P. I 497 (Fr.) (holding the artist could refuse to deliver a commissioned portrait even after exhibiting it); Rouault c. Consorts Vollard, Trib. Seine, 1947, JCP 1947, II, 3405, note Desbois (Fr.) (holding an art dealer's heirs had no claim to an artist's unfinished paintings stored at the dealer's gallery); Soc. Le Chant de Monde c. Soc. Fox Europe et Soc. Fox Américaine Twentieth Century, Cour d'appel [CA] [regional court of appeal], Paris, Jan. 13, 1953, Gaz. Pal. 1953, 2, 191 (Fr.) (enjoining performances of a Soviet propaganda film that incorporated Shostakovich's score without his permission); see also Heide, supra note 20, at 246 (examining the right of disclosure in France); Liemer, supra note 11, at 52-54.

22 Code de la propriéte intellectuelle art. L121-4 (granting an author the right to withdraw his work, even after transferring or publishing it: "[L]'auteur, même postérieurement à la publication de son oeuvre, jouit d'un droit de repentir ou de retrait vis-a-vis du cessionnaire."); see also Law 57-298, supra note 14, art. 32; Carco c. Camoin, Cour d'appel [CA] [regional court of appeal], Paris, 1931, D.P. II 88 (Fr.) (ordering destruction of canvases the artist had slashed up and thrown in the gutter, when a dealer tried to sell them pieced back together); Liemer, supra note 11, at 54-55.

23 See Liemer, supra note 11, at 44 ("Moral rights seek to protect the artist's creative process by protecting the artist's control over that process and the finished work of art."); Vera Zlatarski, 'Moral" Rights and Other Moral Interests: Public Art Law in France, Russia, and the United States, 23 COLUM.-VLA J.L. \& ARTS 201, 203 (1999) (stating that le droit moral stems from a "belief that the subjectivity of creators deserves unquestioning protection').

24 See Liemer, supra note 11, at 43 ("The unique relationship between an artist, the creative process, and the resultant art makes an artist unusually vulnerable to certain personal harms. The art an artist produces is, in a sense, an extension of herself.'); Martin A. Roeder, The Doctrine of Moral Right: $A$ Study in the Law of Artists, Authors and Creators, 53 Harv. L. REv. 554, 557 (1940) ("When an artist creates... he does more than bring into the world a unique object having only exploitive possibilities; he projects into the world part of his personality and subjects it to the ravages of public use.").

${ }_{25}$ See Davidson, supra note 6, at 586.

26 The Berne Convention's right of integrity prevents modifications of an author's work "which would be prejudicial to his bonor or reputation." Berne Convention, supra note 18, art. 6 bis 1 (emphasis added).

27 Law 57-298, supra note 14, at n.2723.

${ }^{28}$ In the United States, a painter, sculptor, or art photographer has "the right to prevent the use of his or her name as the author of the work of visual art in the event of a distortion, 
this special consideration in the law for creative decision making and how the French law came to value the honor and reputation of those who create is the subject of my study and the rest of this Article.

\section{WHERE WERE THE EARLIEST ORIGINS OF LE DROIT MORAL?}

\section{A. ANCIENT ROME}

The natural place to look for the earliest precursor to a French legal concept is in the law of ancient Rome. Most of Western Europe's legal systems have descended from Justinian's Corpus Juris Civilis, ${ }^{30}$ which developed from earlier Roman law. ${ }^{31}$ The ancient Romans had many types of creative work that we

mutilation, or other modification of the work which would be prejudicial to his or her bonor or reputation." 17 U.S.C. $\$ 106 \mathrm{~A}(\mathrm{a})(3)(\mathrm{A})(2006)$ (emphasis added). The same visual artists have "the right to prevent any intentional distortion, mutilation, or other modifications of that work which would be prejudicial to his or her bonor or reputation. ..." Id. (emphasis added). But see Bird, supra note 12 , at 10-12 (discussing this law's effect of constricting artists' rights more than before its enactment).

29 The French statute still includes specific references to the "honor and reputation" of the author in provisions for software designers and state employees, where affirming this underlying consideration was deemed necessary when limiting their moral rights. Code de la propriété intellectuelle art. L121-7 (Fr) (prohibiting a software author from objecting to modification to the software after transferring it, when modification is not prejudicial to his honor or reputation: "[L]'auteur d'un logiciel, ... ne peut. ... [s]opposer à la modification du logiciel. . . lorsqu'elle n'est préjudiciable ni à son honneur ni à sa réputation, ...." (emphasis added)); id. art. L121-7-1 (prohibiting a state employee from objecting to modification of a work when the modification will not affect his honor or reputation: "L'agent ne peut:... [s]'opposer à la modification de l'oeuvre..., lorsque cette modification ne port pas atteinte à son honneur ou à sa réputation." (emphasis added)).

30 See JOHN HENRY MERRYMAN \& ROgelio PÉREZ-PERDOMO, THE Civil Law Tradition 613 (3d ed. 2007); RUSS VERSTEEG, LAW IN THE ANCIENT WORID 270 (2002) ("[R]oman law is the basis for all of the laws in western Europe (including Scotland), except England and Scandinavia. There is even a significant influence in English law.'). Although Napoleon's drafters relied on Justinian's work when codifying the French law, before the French army marched through much of Europe, MERryman \& PÉREZ-PERDOMO, supra, at 10; VERSTEEG, supra, at 281, the influence of Roman law throughout Europe far predates Napoleon. See MERrYMAN \& PÉrEz-PERdomo, , supra, at 8 ('What civil lawyers commonly refer to as 'the revival of Roman law' is generally conceded to have had its beginning ... in the eleventh century. There was, however, an earlier revival of interest in the Corpus Juris Civilis in the ninth century, . . . '); SIVA VAIDHYANATHAN, Copyrights and Copywrongs, THE Rise of INTEllectual Property and How It THREATENS CREATIVITY 41 (2001) ("Renaissance Europe was busy adopting the rediscovered Roman legal code....'); PAul Vinogradoff, Roman LAw in MEdieval Europe (1929) (providing the classic work on point).

31 See Merryman \& PÉREZ-PERDomo, supra note 30, at 7 (stating Justinian "sought to rescue the Roman legal system from several centuries of deterioration and restore it to its former purity and grandeur"); id. at 57 (explaining that "[m]uch of the most important parts of Justinian's Corpus Iuris Civilis ... is made up of the work of jurisconsults" from earlier centuries); VERSTEEG, supra note 30 , at $271-80$. 
would characterize as intellectual property, including many of the types of works now protected by le droit moral. The ancient Romans did not have a modern conception of intellectual property, however, and they did not have a separate body of law for intellectual property. ${ }^{32}$ They believed that the Muses spoke through an artist, and any success was a sign of his proximity to the gods. ${ }^{33}$ In addition, the law of imperial Rome specifically prohibited monopolies for individuals, discouraging legal protection for individuals' interests in creative work. ${ }^{34}$

Professor Katharina de la Durantaye has examined the non-economic protections granted to Roman literary work, for which legal norms can be traced via the written record. 35 She describes evolving social views of creative work and those who created it, during the long time period of ancient Rome's civilization. ${ }^{36}$ Without a body of intellectual property law, "[a]ncient Rome saw to the protection of [literary] authors' interests . . . by means of powerful social norms governing public morals and individual honor.'"37 Professor de la Durantaye concludes that "[t] hose authorial interests which today's droits morals or moral rights oversee were protected by those social norms." 38 Industry custom also played a role in protecting creative work, as did other laws that touched creative work tangentially. ${ }^{39}$

32 See Harry Ransom, The First Copyright StatuTe 19, n.4 (1956); Katharina de la Durantaye, The Origins of the Protection of Literary Autborship in Ancient Rome, 25 B.U. INT'L L.J. 37, 38 (2007) (stating that 'in ancient Rome authors' interests were offered no comprehensive legal protection').

33 See de la Durantaye, supra note 32 , at 108.

34 See F.D. Prager, The Early Growth and Influence of Intellectual Property, 34 J. PAT. OFF. SOC'Y 106, 114-16 (1952) (explaining the prohibition of monopolies in Zeno's law); Craig Allen Nard \& Andrew P. Morriss, Constitutionalizing Patents: From Venice to Philadelphia, 2 REV. L. \& ECON. 223, $256 \& \mathrm{n} .127$ (2006) (tracing the long-term influence of Zeno's law on both the Corpus Juris Civilis and Blackstone).

35 Any picture of ancient creative work of course is limited by the examples that survive to our day. See de la Durantaye, supra note 32, at 39 n.2, citing CATHERINE SALIES, LIRE À ROME 44 (1992) (listing known Roman writers of the first century and stating works now remain for only 26 out of 206 of them).

36 See de la Durantaye, supra note 32, at 39 ("The social rank of the author as well as the literary genre in which he or she operated was dependent upon the period in which he or she wrote... .'); id. at $40-44$ (explaining that, depending on the time period, most ancient Roman writers were retiring politicians, career magistrates, members of the local Italian ruling class, people outside that class rising in social status, members of political opposition movements, or people from the provinces).

37. Id. at 38 .

38 Id.

39 See, e.g., VERSTEEG, supra note 30, at 318 (explaining how the Roman concept of specificatio determined ownership of a newly made thing, with the example of a sculptor using stone owned by another person to create something entirely new); id. at 319 (explaining how the Roman concept of accessio determined ownership of joined objects, with the example of a painter creating 
Looking at the specific moral rights, although ancient Roman writers did not have a legally-protected right of disclosure, a publisher did not want to disrespect a writer's wishes and risk having a potentially profitable work offered to a competitor. ${ }^{40}$ Even more important, however, was protecting the relationship between the two individuals involved. For example, Cicero once gave a work to his longtime publisher, Atticus, for some preliminary critique. While Cicero continued to work on the piece, a third party got ahold of Atticus' copy. The third party was publishing the early version before Cicero could even properly present the dedication of the work. ${ }^{41}$ So Cicero wrote a sharp letter to Atticus. ${ }^{42}$ It contained no threat to sue or references to laws. It made clear that Atticus had greatly insulted Cicero and had violated the trust and social expectations governing both their social friendship and their writer-publisher business relationship. ${ }^{43}$ More typically respectful of the duty owed a friend, two friends entrusted with Virgil's writing refused to publish his Aeneid posthumously, because Virgil had considered it incomplete. ${ }^{44}$

Likewise, no legally-recognized right of attribution existed in ancient Rome. Although originality in writing was not valued in quite the same way it is today, ${ }^{45}$ the Romans definitely disapproved of plagiarism. ${ }^{46}$ A well-known work or excerpts from it could not be misattributed without social repercussions, because literate people would recognize the original and the breach of social mores. ${ }^{47}$

Finally, without any law on the right of integrity, the integrity of literary work received protection indirectly. No legal cases concerning changes to a writer's work are recorded, but writers certainly complained about bad proofreading and changes to their texts. ${ }^{48}$ Here again the marketplace and

\footnotetext{
a picture on a canvas belonging to another).

40 See de la Durantaye, supra note 32, at 58-59. In ancient Rome, a publisher employed highly skilled slaves or free men to copy books by hand. A run of a thousand copies or more was not unheard of. $I d$. at 49.

41 See id. at 62-63.

42 CiCero, EPISTUlaE AD ATTICUM 13.21.4, cited in de la Durantaye, supra note 32, at 63, n.149.

43 See de la Durantaye, supra note 32, at 25-26.

44 See id. at 65 . Eventually Augustus forced publication. This example also shows that the duties owed a friend and writer extended post-mortem.

45 See id. at 70 (explaining that writers followed established literary forms, did not need to create original themes or stories, and borrowed from others to compliment them, not to rip off their work).

46 See id. at 68-69, 71; Swack, supra note 5, at 366 (explaining that not recognizing the writer of a work accurately was considered a type of theft).

47 See de la Durantaye, supra note 32 , at 70-71.

$48 I d$. at 73-75. Copies proofread by the writer himself sold at a premium. Id. at 75 .
} 
social norms ruled, as the more prominent writers were able to work with the more conscientious and reliable publishers. ${ }^{49}$

In ancient Rome, dramatic works received special treatment under state authority, because they reached a much wider audience. ${ }^{50}$ Once approved for performance by special magistrates, scripts rarely were changed.51 "This protection was not conceived of to protect the author's rights, but instead the protection of the cultural heritage of which it was a part...."52 Thus, theatrical "productions ... remain[ed] remarkably faithful to their texts." 53

Although it is tempting to view the ancient Roman protections as forecasting the modern rights, they differed in important ways. Most obvious, the extent of these protections would at best make them only rudimentary precursors to le droit moral. ${ }^{4}$ More profound, however, is the difference in the conceptual nature of the protection given to creative work..$^{55}$ In ancient Rome, this protection depended on a relationship between two individuals (usually elites) and the duties they owed each other based on that relationship, and it was recognized and enforced mostly by social norms. The creative process per se did not engender these protections, an author standing alone ${ }^{56}$ did not embody any special protection, and the protections were not the types enforced in court.

Thus, it is hard to find genuine precursors to le droit moral in the law of ancient Rome. Some of the same interests were accounted for by the society, and writers, mostly elites or aspirants, wanted social recognition and respect. But no unbroken line of law can be found connecting ancient Rome to the

\footnotetext{
49 Id. at 74 .

50 Theater was the broadcast medium of the day.

51 See de la Durantaye, supra note 32, at 84-87 (explaining the role of the aedelis curules, who also supervised initial productions).

52 Id. at 87 . Efforts to preserve cultural heritage helped protect the integrity of the originals of written work at least as early as the ancient Greek library at Alexandria. Peter S. Menell, Knowledge Accessibility and Preservation Poligy for the Digital Age, 44 Hous. L. REV. 1013, 1019-21 (2007); see also Merryman, supra note 20, at 1041 (explaining the obverse, that protecting the integrity of art protects a society's identity).

53 de la Durantaye, supra note 32 , at 87.

54 For example, Professor de la Durantaye's conclusions only apply to writers and not to sculptors, painters, actors, musicians, and other types of artists in the ancient Roman Empire. In addition, even among writers, her findings suggest the protections were most effective for males with social and professional prominence, leaving questions about the protection for female and less elite male writers.

55 See de la Durantaye, supra note 32, at 58 (warning that "contemporary terms and concepts can only be of limited help in elucidating the social and economic conditions, and the legal systems, which prevailed under the Roman Empire.").

56 "When a society does not consider an author as an individual creator of works, this society is unlikely to see a need to develop instruments for the protection of his or her interests." Id. at 99100.
} 
modern law of le droit moral. The creative process was not protected for its own sake as the expression of an individual's own consciousness. Le droit moral did not exist as individual, legally-protected human rights.

\section{B. RENAISSANCE EUROPE}

Core perceptions of creative work and those who created it had to change before conditions arose in which le droit moral could develop. Early concepts of intellectual property and intellectual property law gradually began to emerge as the Middle Ages bloomed into the Renaissance.

In the Middle Ages in Europe, visual, performing, and literary artists usually worked for wealthy patrons, ${ }^{57}$ either individuals or institutions. Artists were still perceived as receiving divine inspiration, and creative work usually extolled some aspect of the dominant Christian religion. ${ }^{58}$ Typically artists in many creative fields created under the auspices of a patron, with contracts for specific commissions. ${ }^{59}$ In addition to the artist, the patron was perceived as someone who was responsible for making the work. ${ }^{60}$ Artists were considered craftsmen, ${ }^{61}$ simply executing the vision of their patrons. ${ }^{62}$

Most types of creative work also came to be regulated by guilds. ${ }^{63}$ In the guild system, apprentices and journeymen worked under a master, and several people in that master's workshop often helped create a single work. ${ }^{64}$

Thus in the Middle Ages and early Renaissance, a work was not perceived as the creative product of one individual. ${ }^{65}$ Patrons dictated the medium, subject

57 See Dan Rosen, Artists' Moral Rights: A Eumpean Evolution, an American Revolution, 2 CARDOzO ARTS \& ENT. L.J. 155, 166 (1983) (stating that through the fourteenth century art was not a career for the upper middle class and nobility; artists were poor men).

58 In this time period still, "[a]rt was functional and utilitarian; it was generally devotional, didactic, or decorative, and preferably all three. The artist's work was not self-expressive in the sense that we value individual self-expression and originality today. ..." Evelyn Lincoln, Invention and Autborship in Early Modem Italian Visual Culture, 52 DEPAUL L. REV. 1093, 1095 (2003).

59 See id. at 1095 (isting details in a good Renaissance art commission contract).

60 See Note, Exploitative Publishers, Untrustwortby Systems, and the Dream of a Digital Revolution for Artists, 114 HARv. L. REV. 2438, 2439-40 (2001) ("[P]atrons enjoyed the attribution of authorship to creative works. Writers served patrons as craftsmen, and the patron 'symbolically took title' to a work he endorsed.").

61 See Rosen, supra note 57, at 166 (describing medieval artists as "without distinction from those who toiled at other crafts").

62 See generally Lincoln, supra note 58, at 1095-97.

63 See, e.g., Frank D. Prager, $A$ History of Intellectual Property from 1545 to 1787, 26 J. PAT. OFF. SOC'Y 711, 713 (1944) (describing aspects of guild control); Rosen, supra note 57, at 166-67 (reporting painters' growing independence within the physicians and apothecaries' guild of fourteenth century Florence).

64 See Lincoln, supra note 58, at 1097.

65 See Roberta Rosenthal Kwall, Originality in Context, 44 Hous. L. REv. 871, 872 (2007) 
matter, and many of the details of a work, ${ }^{66}$ and the master artist assigned specific tasks to workshop artists and regulated the work's style. ${ }^{67}$ As the Renaissance developed, a successful artist could be hired into a long-term position in-residence with a patron, with more job security, more creative leeway, ${ }^{68}$ and fewer restrictions by any relevant guild. ${ }^{69}$ Still, "renaissance observers can glide between a sense of the patron as author and a sense of the artist as author in a way that is hard to follow."'70 The concept of an individual artist had to develop before the concept of rights for an individual artist could develop.

The creation of a written text, a manuscript, also was not a solitary pursuit in medieval Europe. ${ }^{71}$ A person who wrote poems and plays typically relied on a patron for financial support. ${ }^{72} \mathrm{~A}$ third person, a scribe, handwrote the work, ${ }^{73}$ and yet another person might create the pictures and other decorative elements in a manuscript. A writer borrowed liberally from many sources, and such borrowing was thought to flatter the original writer and lend some of the

(explaining that the Renaissance did not view an author as "personally responsible for his work"); Rosen, supra note 57, at 164 (explaining that the thirteenth and fourteenth century artist was a member of "a collective work organization").

66 See Lincoln, supra note 58, at 1093-95 (describing a legal dispute that arose when an artist failed to include the expected number of apostles in a painting); Rosen, supra note 57, at 167 (" $[\mathrm{M}]$ asters ... were restrained by the desires of their patrons.").

67 See Rosen, supra note 57, at 166 ("The master was . . expected, to specify 'proper' painting, thus restricting artistic options.").

68 See Lincoln, supra note 58, at 1097 (reporting on an artist who chose court life "where ... he would have more artistic control"); id. at 1119 n.10 (referring to "Renaissance courts as the locus of the formation of artistic careers that seem to have fashioned modern ideas about the creative freedom of artists, ...').

69 See Lincoln, supra note 58, at 1099; Paul Edward Geller, Copyright History and the Future: What's Culture Got to Do with It?, 47 J. CoPYRIGHT SOC'Y U.S.A. 209, 223 \& n.79 (2000) (outlining the progression from guild ties to 'individual privileges and titles as members of aristocrats' retinues").

70 Lincoln, supra note 58, at 1097.

71 A lot of writing is reverting back to being a collective activity in our own time. See Martha Woodmansee, On the Author Effect: Recovering Collectivity, in THE CONSTRUCTION OF AUTHORSHIP: TeXtual ApPropriation In LAW and Literature 15, 24-25 (Martha Woodmansee \& Peter Jaszi eds., 1994) (describing the "collaborative nature" of much of today's writing); Steven D. Jamar, Crafting Copyright Law to Encourage and Protect User-Generated Content in the Internet Social Networking Context, 19 WIDENER L.J. 843 (2010) (proposing copyright law changes to accommodate social networking, fan fiction, and other writing created collectively on the Internet).

72 See Cynthia J. Brown, Poets, Patrons, and Printers: Crisis of Authority in late MEDIEVAL FRANCE 106 (1995) ("[T] he author's writing represented his personal rendition of the patron's desires, needs, or image, .... [T] [Te writer possessed an outlet for his talents; the patron, a vehicle for self-display.").

73 See id. at 2 (referring to "the hierarchical triad of patron, poet, and scribe"). 
reputation of the original work to the new work. ${ }^{74}$ Scribes also inserted changes, so no two copies of a manuscript were quite the same. ${ }^{75}$ In this "manuscript culture," an appointment in a noble household in exchange for the production of manuscripts was considered an exchange of courtesies, an exchange of gifts. ${ }^{76}$

By 1500 , a few individual visual artists were rising to such prominence that they were able to begin to change the paradigm. ${ }^{77}$ Michelangelo Buonarroti is generally reported to be the first visual artist to have asserted his personal rights as the author of a work. ${ }^{78}$ For example, when he was painting the Sistine Chapel from 1508 to 1512 , he repeatedly refused requests from his patron, Pope Julius, to see how the work was progressing. When Pope Julius eventually insisted on showing up in person to view the work, Michelangelo physically blocked the Pope from entering the Chapel. He asserted that he had the right as an artist to say when the work was ready to be disclosed. ${ }^{79}$ In another incident, Michelangelo chiseled his name on a sculpture surreptitiously to assert accurate attribution. ${ }^{80} \mathrm{He}$ also was able to assert the right of integritydeciding for himself what to depict and how to depict it-for those works that he created without a commission or patron; his reputation was so great, he found buyers after completing works he initiated. ${ }^{81}$

Centuries would pass before asserting individual rights of authorship became the norm for more obscure artists, but at this time a visual artist working as an individual to satisfy his own artistic standards became an

74 See id. at 29 (" $[$ P]lagiarism, or the unlawful appropriation of another's words and ideas, could not have existed in medieval times. What eventually became illegal ... originally constituted ... the very nature and substance of medieval literary creation.").

75 See id. at 28 (explaining the concept of mouvance in medieval literature); id. at 202-03 (suggesting a scribe's role sometimes approached that of an editor or author). For a detailed discussion of the medieval origin of the word "autewr" ("author") and the changing concepts behind it, see id. at 198-206; see also Woodmansee, supra note 71, at 17 (describing the roles different individuals played in creating a text).

76 BROWN, supra note 72, at 109, quoting Sharon Kettering, Gift-Giving and Patronage in Early Modem France, 2 FRENCH HIST. 135 June 1988) (referring to "the polite fiction that service was freely given because gift-giving was more a courtesy than a compulsorily reciprocal act" ").

77 See Rosen, supra note 57, at 168 (designating Giotto as the first celebrity artist of the Middle Ages and Leonardo da Vinci as the first superstar among artists).

78 See id. at $170-72$.

79 Id.

80 Id. at 171 (quoting G. VASARI, The Lives OF THE PAINTERS, SCulPTORS AND ARChITECTS 71 (A.B. Hinds trans. 1927)); Natalie C. Suhl, Note, Moral Rights Protection in the United States Under the Beme Convention: A Fictional Work?, 12 Fordham INTELL. Prop. MEdia \& ENT. L.J. 1203, 1206 (2002) (reporting the incident). Other artists began to assert their identities by including images of themselves in their work. Rosen, supra note 57 , at $171 \mathrm{n.85}$.

81 See Rosen, supra note 57, at 172; see also Geller, supra note 69, at $223 \mathrm{n.79}$ (outlining the progression of Italian Renaissance artists towards "professional independence"). 
acknowledged possibility. Michelangelo began a paradigm shift. ${ }^{82}$ No law protected Michelangelo's rights of disclosure, attribution, or integrity; only his reputation did. Force of reputation would have to become force of law before visual artists could really be said to enjoy the protection of le droit moral, but prerequisite changes in underlying concepts were starting to take place.

Technological advances in general, and the printing press in particular, also contributed to the change in perceptions. At first, by applying familiar legal concepts, ${ }^{83}$ the medieval royal privileges related to land use, such as permission to hunt in a particular wood, were extended to manufacturing activities on the land, such as permission to extract salt from a particular salt mine. ${ }^{84}$ As early as the fourteenth century, European rulers began to grant specific exclusive rights, for limited time periods, to help develop particular industries. ${ }^{85}$ A sovereign usually closed a written communication with the royal seal, but notice of these special monopolies, with the imprimatur of the royal seal, were left open, to inform the public about them. ${ }^{86}$ They came to be known as letters patent, open letters. ${ }^{87}$ Early patents covered many different industries and activities, from

82 Inevitably the shift in perceptions depended on the medium in question and the ways in which it was locally supported; vestiges of the medieval patronage system lasted for centuries later. See, e.g., Geller, supra note 69, at 223-24 (providing examples of famous European writers and composers "subject to patrons' whims" through the eighteenth century); Jane C. Ginsburg, The Concept of Authorship in Comparative Copyright Law, 52 DEPAUL L. REv. 1063, 1090-91 \& nn.117, 118 (2003) (arguing that "this creator-centric approach to authorship" is a much more recent development). Professor Ginsburg cites an 1826 French court decision that asserts the word "authors... designates 'not only those who themselves created a literary work, but also those who have had the work composed by others, and who undertake to pay for its composition." 'Id. (citing L'Affaire du Dictionnaire de l'Académie Française, reported in 1 Dev. \& Car. 1.806 (Devilleneuve et Carette, Receuil général des lois et des arrêts, 1re série 1791-1830) ("Le mot. ... désigne, non seulement ceux qui on composé par eux-mêmes un ouvrage littéraire, mais encore ceux qui l'ont fait composer par d'autres, et qui en ont pris la composition à leur compte.")).

83 See Gregory N. Mandel, History Lessons for a General Theory of Lan and Technology, 8 MINN. J.L. SCI. \& TECH. 551, 553 (2007) ("The routine response to new issues . . . is to try to analogize them to existing legal categorization .... But, where the new issue arises as a result of technological change, the old categories may no longer apply.").

84 See Prager, supra note 34, at 123 (describing medieval privileges for land-related manufacturing-like mining, forestry, and mills on river channels-as "quasi-patents").

85 See id. at 118-22 (describing the gradual evolution of these privileges, in part to protect local secrets); see also Oren Bracha, The Commodification of Patents 1600-1836: How Patents Became Rights and Wby We Should Care, 38 LoY. L.A. L. REV. 177, 183 n.19 (2004-2005) (reporting an English letter of royal protection for cloth maker John Kempe as early as 1331); Prager, supra note 63, at 714 (explaining the terms of a 1332 Venetian privilege for a windmill); Rosen, supra note 57 , at 168 n.78 (reporting the same privilege).

86 See 2 WILIIAM BLACKSTONE, COMMENTARIES *346 (" [T] hey are not sealed up, but exposed to open view, with the great seal pendant at the bottom; and are usually directed or addressed by the king to all his subjects at large.").

87 Id. (explaining literae patents, letters patent or open letters); Chris Dent, Patent Policy in Early 
iron works to hat-making. ${ }^{88}$ These limited monopolies were issued by other authorities, too. ${ }^{89}$ Thus the concept of giving exclusive, legal protection to an individual for a particular kind of work developed.90

In addition, the guilds gradually developed the "unity of work" requirement, ensuring quality by making sure a product came from just one producer who could be held responsible for it. Holding an individual responsible also led to assigning value to an individual's work. ${ }^{91}$

By 1469, John Speyer, a master book printer, received a privilege in Venice giving him the exclusive right to print books in the city for five years. ${ }^{22}$ The written document recording the privilege says the city councilors decreed it "in the same manner as usual in other useful arts."93 Thus in the earliest days of printing, this monopoly privilege was perceived to be similar to the privileges granted for other trades. ${ }^{94}$

Printing of course proved to be an unusual activity, with a particularly important influence on early concepts of intellectual property and intellectual

Modern England: Jobs, Trade and Regulation 3, available at http://ssrn.com/abstract=1001611 (2007) ("The term 'patent' is a shortened form of 'letters patent' or 'open letters." ").

88 See Bracha, supra note 85, at 185-90 (reporting specific early English "patent deals"); Dent, supra note 87, at 3-5 (explaining four categories of early English patents).

89 See, e.g., Rosen, supra note 57, at 169 n.78 (reporting that in 1432 the General Welfare Board of the Republic of Venice issued the first patent statute, promising an exclusive privilege to anyone who could improve the silk-making process); Prager, supra note 63, at 715,750 (referring to the more generally applicable Venetian patent privilege statute of 1474); Nard \& Morriss, supra note 34 , at 233-37, 247-57 (detailing the forces leading to the development of early Venetian patent laws); Prager, supra note 34, at 125-26 (describing the procedure for obtaining "quasipatents" from Venice's General Welfare Board and the scope of such monopolies); id. at 130-33 (providing more details on the development of the early Venetian patent statutes); ELIZABETH ARMStRong, BEFORE COPYRIGHT: ThE FRENCH BOOK-PRIVILEGE SYSTEM 1498-1526, at 12-20, 55-62 (1990) (describing later book printing privileges issued by the Pope, the Holy Roman Emperor, local church officials, dukes, and universities).

20 See Bracha, supra note 85, at 184 (cautioning that early "patent-privileges" were distinct from modern patent rights).

21 See Prager, supra note 34, at 129 (asserting that "unity of work" requirements led to the modern trademark right).

92 See Jobannes of Speyer's Printing Monopoly (1469), available at http://www.copyrighthistory.org/c gi-bin/kleioc/0010/exec/ausgabe/\%22i_1469\%22 (last visited Sept. 28, 2011) [hereinafter Printing Monopoly] (providing a facsimile, transcription, and English translation of Speyer's privilege, dated Sept. 18, 1469); Prager, supra note 63, at 750 (providing excerpts of the original grant in English translation).

93 Printing Monopoly, supra note 92, at http://www.copyrighthistory.org/cgi-bin $/ \mathrm{kleioc} / 0010 / \mathrm{ex}$ ec/showTranslation/\%22i_1469\%22/start/\%22yes\%22 (" $[q]$ uemadmodum in aliis exercitiis sustentandis'); Prager, supra note 63, at 750.

94 See Prager, supra note 34, at 134 (explaining "the printer's monopolies were simply a special kind of patents"). 
property law during the Renaissance. ${ }^{55}$ The printing trade took root in Northern Italy first, ${ }^{96}$ in the same locations where the Renaissance flourished. From there, it spread north into France and other countries. ${ }^{97}$ As printing became more widely used, its new ways of creating works helped further develop the new ways of perceiving authors. ${ }^{98}$ The newfound ease of creating multiple copies had a particularly profound effect.

In Northern Europe, Albrecht Dürer shared his contemporary Michelangelo's star status. ${ }^{99}$ As a renowned engraver, Dürer enjoyed considerable financial independence because he could easily strike multiple prints to sell, all from one plate. ${ }^{100}$ Able to mass market his work, he had no need for patrons or guilds. ${ }^{101}$ But the nature of Dürer's medium also required more than an international reputation to protect his work; easy dissemination and copying required some type of more wide-reaching means of protection. ${ }^{102}$ As printing technology spread throughout Europe, the ease of transporting and duplicating texts and images made pirating relatively easy. ${ }^{103}$ Thus printers,

95 See Peter Lindenbaum, Milton's Contract, in THE CONSTRuCtION OF AuTHORSHIP: TEXTUAL. APPROPRIATION IN LAW AND LITERATURE 175, 175 (Martha Woodmansee and Peter Jaszi, eds., 1994) (citing Elizabeth L. Eisenstein, The Printing PREss as an Agent of Change (1979)) (stating the concept of independent artists with rights is "one of the long-term results of the introduction of print").

96 See Neil Weinstock Netanel, Maharam of Padua v. Giustiniani: The Sixteenth-Century Origins of the Jesish Law of Copyright, 44 Hous. L. REV. 821, 831 (2007) (describing Venice as the capital of printing in Europe by 1480); see also id. at 833-35 (describing the competitive nature of the Venetian printing industry for the next 100 years).

97 The Renaissance flow of ideas from Northern Italy to France is particularly relevant to this Article's inquiry because printing privileges were common in Milan before France's King Louis VII won control of the city. See ARMSTRONG, supra note 89, at 5, 6. Some individuals who published with a ducal privilege in Milan then published with a French royal privilege, reinforcing the nascent practice in France. See id. at 24-25.

98 See Bracha, supra note 85 , at 180-81 (describing the "general trajectory . . from privileges to rights"); Davidson, supra note 6, at 593 (noting incremental changes in concepts of authors, from "consigned to the periphery of the publishing business" to "autonomous individuals whose work flowed from an intensely personal process"); Lincoln, supra note 58, at 1101 ("The increasing use of the printing press for both textual and pictorial printing over the course of the sixteenth century went hand-in-hand with changes in ideas about how and for what reasons to express authorship.").

99 Dürer lived from 1471-1528; Michelangelo from 1475-1564.

100 See Lincoln, supra note 58, at 1107 (describing how Dürer used prints like money, to pay for goods and service). Two centuries later, engravers also held a unique position in the history of Anglo-American intellectual property law. See Susan P. Liemer, How We Lost Our Moral Rigbts and the Door Closed on Non-Economic Values in Copyright, 5 John Marshall Rev. InTEid. Prop. L. 1, 14-19 (2005) (analyzing the Engravers' Act, 8 Geo. 2, c. 13 (1735) (Eng.), and the ways in which it protected non-economic values of creative work).

101 See Rosen, supra note 57, at 174 n.95.

102 See id. at 174.

103 Although pirating printed works involved risks, it also involved enough profits for successful 
publishers, writers, and engravers had a particular reason to seek protection from rulers in the form of privileges and monopolies. ${ }^{104}$ Soon privileges for the industry of printing evolved into an exclusive printing privilege for a particular text or image. 105 Rulers had multiple reasons to grant such protections, 106 although early on, particularly in France, control of the printed message was not foremost among those. ${ }^{107}$

\section{EARLY SIXTEENTH CENTURY FRANCE}

At the same time that Michelangelo and Dürer were gaining the protection of international reputations, a small spark ignited in France. All of the players in the new French printing industry began to sort out their interests, and some French writers began to assert a new sense of authorship. Their efforts to protect their work are the most rudimentary precursors of French intellectual

commercial networks to develop. See Geller, supra note 69, at 220 (stating that by the seventeenth century, "France, with porous borders and a large land-mass hard to police, found its provincial book markets well supplied by smugglers, renegade printers, and peddlers"); Robert Darnton, The Life Cycle of a Book: A Publishing History of D'Holbacb's Système de la Nature, in PUBLISHING AND READERSHIP IN REVOLUTIONARY FRANCE AND AMERICA 15-16 (Carol Armbruster ed. 1993) (describing a well-established trade network for pirated French books in the eighteenth century).

104 See Lincoln, supra note 58, at 1118-19 ("The new trade of printmaking, which was both lucrative and at first completely free of guild regulation, was responsible for pressure that resulted in a new precision about distinguishing the roles of the designers, printmakers, and publishers involved in the creation of a printed image."); Geller, supra note 69, at 210 ("Only when media technology and market conditions made piracy profitable could copyright arise." (emphasis omitted)); ARMSTRONG, supra note 89, at xi (stating "economic pressures which authors and publishers were experiencing, not under government legislation," caused book privileges to develop).

105 See ARMSTRONG, supra note 89 , at 2-4 (describing the earliest privileges for printing specific books in Germany and Italy); of. Netanel, supra note 96, at 834 (noting these protections were limited by jurisdiction).

106 See, e.g., Dent, supra note 87, at 25-27 (summarizing elite interests protected by "copyright" in early Jacobean and Elizabethan England).

107 See ARMSTRONG, supra note 89, at 17 (suggesting the Reformation caused government oversight of the content of books); id. at 100 (explaining writers applied for early printing privileges for the perceived benefits, not as "part of any organised system of licensing"); id. at 207 (stating that in this early period in France privileges "did not form part of any system of ... censorship"); Geller, supra note 69, at 216 (explaining that "the French Crown only progressively centralized jurisdiction over the media").

In addition, book printing privileges were easy favors to bestow because they "cost the Crown nothing to give." ARMSTRONG, supra note 89 , at 27 ; see also BROWN, supra note 72 , at 53 (explaining that the king could give a privilege without providing the direct economic support of a patron, which was a change to the patronage system). See David E. Miller, Finding a Conflicts Issue in International Copyright Litigation: Did the Second Circuit Misinterpret the Beme Convention in Itar-Tass?, 8 CARDOZO J. INT'L \& COMP. L. 239, 248 (2000) (noting sovereign protection also conveniently allowed sovereign review for subversive content). 
property law, including le droit moral. In her detailed catalogue and study of early French book privileges, ${ }^{108}$ Professor Elizabeth Armstrong dates the first printing privilege for a specific book in France to $1498,{ }^{109}$ and the practice of literary writers seeking a privilege for their work caught on quickly a decade later, ${ }^{110}$ likely in response to a remarkable lawsuit.

On April 30, 1504, the literary writer André de La Vigne brought suit in Paris against the printer Michel Le Noir. ${ }^{111}$ La Vigne had an agreement with another printer, Pierre Le Dru, to print Vergier d'bonneur, an anthology of poems (some by La Vigne, some by other writers). ${ }^{112}$ Michel Le Noir was in the process of printing the work without La Vigne's permission when the writer sued for protection from the unauthorized printer. ${ }^{113}$ Note that Pierre Le Dru, who was undertaking the expenses of book manufacturing and now had direct economic competition, did not sue. ${ }^{114}$ It was the writer, the literary artist, who sued for control over his own creative work.

The court granted La Vigne a two-week recess in which to find witnesses, ${ }^{115}$ and they apparently showed up. There were other writers willing to testify against Le Noir's practices and to assert their need for protection. ${ }^{116}$

108 See ARMSTRONG, supra note 89, at 209-95 (listing and dating every known French book privilege from 1498 to 1526 ).

109 See id. at 7, 209 (reporting the 1498 grant of a book printing privilege in France to a physician for a technical medical book).

110 See id. at 206 ("The speed with which the privilege-system became familiar to the educated public in France was remarkable."). Many of these early printing privileges received an authoritative seal, like the letters patent, and used similar written conventions. See id. at 65,78 .

$111 \mathrm{La}$ Vigne likely was encouraged by the success of Guillaume Cop, an almanac writer who just the month before won a lawsuit in Paris against Jean Boissier, a printer selling unauthorized copies of Cop's work (at the time, not an unusual practice). That court decision prohibited Boissier from selling any more of the unauthorized copies. See id. at 35-36 (summarizing the lawsuit and decision); BROWN, supra note 72, at 2 n.3 (suggesting this suit influenced the one brought by André de La Vigne); MARC ROSE, AUTHORS AND OWNERS: THE INVENTION OF COPYRIGHT 19 (1993) (describing the case).

112 See BROWN, supra note 72, at 17-18 (describing the relationship of La Vigne and Le Dru).

113 See id. at 1-2 (describing the lawsuit within the context of its time); Davidson, supra note 6, at 605-06 (describing the lawsuit); ARMSTRONG, supra note 89, at 36 (summarizing the lawsuit).

114 In sharp contrast, English writers were marginalized when English printers sued other printers, first in the equity courts after the Statute of Anne, 8 Ann., c. 19 (1710) (Eng.), was enacted in 1710 , and then in the law courts starting in the $1760 \mathrm{~s}$. See Liemer, supra note 100, at $20-21,23,27,29$.

115 See BROWN, supra note 72, at 255 (providing the original text of this interlocutory decision, dated May 11, 1504, and its location in the French National Archives).

116 At the same time that La Vigne's lawsuit was taking place, the same printer Le Noir was printing a work by Jean Bouchet, but attributing it to another writer. La Vigne's court decision mentions Bouchet's work, indicating Bouchet likely testified for La Vigne. See id. at 4, 25, 189. Of the Parisian writers' efforts generally, "there seems to have been a complicitous solidarity among them .... [c]hallenging certain aggressive publishers ....". Id. at 4. Perhaps La Vigne 
La Vigne won his lawsuit and a ten-month monopoly for printing the work. ${ }^{117}$ He received a printing privilege for his book, prohibiting the sale of the unauthorized copies that had already been made, before a single copy had been sold. The unauthorized printer, Le Noir, lost the investment he had already made to print the books, and he also had to pay both sides' court costs. ${ }^{118}$ Thus, La Vigne gained direct protection for the same interests protected by the right of disclosure. And because he could control who printed his work initially, choosing a trustworthy printer who would work with him, he gained protection for a limited time for the same interests protected by the right of integrity and the right of attribution. ${ }^{119}$

The remedy La Vigne received from the court, a privilege custom-made for his situation, makes plain the lack of any previously-existing redress in the law at the time. He could not rely on any intellectual property statute, body of case law, or established social norms, as none existed. A writer in his situation could only point to the analogous-but not yet common-royal grants of printing privileges for individual books.

After La Vigne won in court, other writers were emboldened to seek privileges before seeking printers. ${ }^{120}$ In 1507, Eloy d'Amerval received the first

chose to sue over an anthology as a calculated move to ensure witnesses, as the other writers with works in that book would be natural allies against an unscrupulous printer.

117 It is hereby declared that the said court ... prohibits ... [Le Noir] and all other booksellers and printers in this city of Paris, except for ... [La Vigne], from printing or selling the books entitled the Vergier d'bonneur..., until next April 1 st, ....

Il sera dit que ladicte Court... fait defenses audit... [Le Noir] et a tous autres libraires et imprimeurs de ceste ville de Paris, autres que ledit... [La Vigne], de ne faire imprimer ne vendre les livres appellez le Vergier de bonneur..., jusques au premier jour d'auril prochain venant, ....

Id. at 1, 256 (providing an English translation and the original French text, dated June 3, 1504, and its location in the French National Archives). See also Davidson, supra note 6, at 606 (reporting the decision); ARMSTRONG, supra note 89, at 36 (summarizing the decision).

118 "[T]he court condemns... [Le Noir] to pay the expenses of these proceedings, the determination of these expenses being reserved for the court."- "[S]i condamne la Court... [ Le Noir] es despens de ceste instance, la tauxacion d'iceulx reservee par devers elle." BROWN, supra note 72, at 12, 256 (providing an English translation and the original text).

119 Proper attribution of a written text was not necessarily given in this time period. See, e.g., id. at 111 (summarizing the same Le Noir's purposeful misattribution of a work by Jean Bouchet); id. at $83,188-89$ (describing Le Noir's replacement of lines identifying the writer Pierre Gringore with lines identifying himself); id. at 158-61 (describing how the writer Jean Molinet's identity disappeared altogether when one of his early works was printed); id. at 194 (stating misappropriation was just "becoming legally acknowledged for the first time in the early sixteenth century"). Once a writer's name was correctly placed on his work, however, the name tended to stay with the work through future editions of it. See, e.g., id. at 89 (reporting that all editions of La Vigne's Vergier d'bonneur, even after his court-ordered privilege expired, displayed his name).

120 See BROWN, supra note 72, at 3 (suggesting the terms of the decision in La Vigne's case 
such pre-emptive book printing privilege in France for which the full text is known. ${ }^{121}$ This pre-emptive privilege was granted to a writer for a monopoly right to decide who would print his work, ${ }^{122}$ to assert control over the initial presentation of his creative work. The privilege was initially for two years ${ }^{123}$ and covered all of France. ${ }^{124}$ Because a privilege was a customized decree from the king (or another noble on behalf of royal interests), ${ }^{125}$ when d'Amerval sought a privilege, he was essentially saying that there was no other way in his society at that time to receive the protection ${ }^{126}$ he sought. Having written the words for a printed text, there was no other legally or socially recognized right to them for him to invoke.

Another literary writer, Jean Lemaire, also ran into problems with the printer Le Noir in April 1504.127 So for his next work in 1509, Lemaire too took the

"resemble so closely what were to become stipulations of privileges that his actions appear to have paved the way for their regularized use by authors some fifteen months later."); id. at 35 (noting that the similarity between a privilege obtained by the writer Pierre Gringore eighteen months later and La Vigne's decision "is remarkable"); id. at 97 (noting that "Gringore had taken action even before publication to head off the sort of pirating that had previously been inflicted on Bouchet, La Vigne, and himself . . . a warning to all Parisian publishers . . . that the author had taken control of book production."); id. at 194 ("La Vigne's successful lawsuit ... served notice to publishers that writers had become aware of the need to play a more active role in the legal and practical appropriation of their works.").

121 Eloy d'Amerval's Privilege (1507), available at http://www.copyrighthistory.org/cgi-bin/kleioc/ 0010/exec/ausgabe/\%22f_1507\%22 (last visited Sept. 28, 2011) [hereinafter d'Amerval's Privilege] (providing a facsimile, transcription, \& English translation of d'Amerval's privilege); Rosen, supra note 57 , at 174 n.96.

D'Amerval, the Choirmaster of Orleans' cathedral, ARMSTRONG, supra note 89, at 101, included the full text of his privilege in the front of his book, id. at 142 .

122 d'Amerval's Privilege, supra note 121 (stating that "he and he alone, and no other, may cause the aforementioned book to be printed by the printer and bookseller of his choosing" — "lui seul et non austre faire imprimer le dit livre dessus declaré p [ar] tel Imprimeur ou libraire que bo[n] luy se[m]blera").

123 Id. (providing the privilege "for the duration of two whole years from the date of issue""iusques à deux ans entiers"). Two or three years quickly became the typical length of time for a book privilege in France. See ARMSTRONG, supra note 89, at 214-95.

124 d'Amerval's Privilege, supra note 121 (enjoining all others "whether in our city of Paris or elsewhere"- "soit de nostre Ville de Paris ou d'ailleurs"). See also ARMSTRONG, supra note 89, at 22 (suggesting the large geographic area made a French royal printing privilege particularly worthwhile for a writer).

125 ARMSTRONG, supra note 89, at 22-55 (explaining various routes to a royal book privilege, via the Chancery, the Parlements-royal law courts that already regulated urban commerce, Prévôts, and other royal officials).

126 The consequence of infringing on d'Amerval's privilege was to be confiscation of the unauthorized copies. d'Amerval's Privilege, supra note 121. Other penalties at this time included steep fines and court costs, but not imprisonment. See ARMSTRONG, supra note 89, at 194-97.

${ }_{127}$ Lemaire had an agreement with the printer Antoine Vérard, to print Temple d'Honneur et de Vertus. The same Michel Le Noir printed the work without permission and produced poorly proofread copies. Even Lemaire's name was misspelled. See BROWN, supra note 72, at 4-5 
still novel approach of obtaining a royal privilege to print the work for three years. ${ }^{128}$ In addition, he proceeded to publish the work with his own money. ${ }^{129}$ On the title pages of the book, he reprinted the privilege and asserted his full ownership and control of the work. ${ }^{130} \mathrm{He}$ made certain that he alone would control the initial presentation and use of his creative work. ${ }^{131}$ He protected the same interests protected by the rights of disclosure, attribution, and integrity. He determined when the work would be disclosed, in what form, and with his name attached only to those copies he approved. The fact he had to publish the work himself and seek a personalized privilege to do so again underscores the reality that these protections were not otherwise recognized. In the early days of printing, there were no intellectual property rights to invoke, either through the law or other social norms.

Lemaire was able to obtain a three-year royal privilege because he had some connections in the royal court. ${ }^{132} \mathrm{He}$ also had enough financial resources to underwrite the publishing of his book without having to depend on someone

(reporting this happened just a few weeks before La Vigne's 1504 lawsuit); id. at 40 (providing more details of the dispute); Davidson, supra note 6, at 607 (summarizing the dispute). Thus, the unauthorized publisher violated the same interests protected by the rights of disclosure, attribution, and integrity.

$128 S_{e e}$ Davidson, supra note 6, at 607 (summarizing the privilege).

129 See BROWN, supra note 72, at 38-59 (detailing the many ways in which self-publishing allowed Lemaire to assert ownership and control of his work). Lemaire even substituted a picture of his own coat of arms for the king's fleur-de-lis, id., as he "assume[d], legally and metaphorically, the function of sovereign in and of his text ...." Id. at 3, 49 .

130 See ARMSTRONG, supra note 89, at 22 (explaining no original documents of early French book privileges have survived, but the text was often printed, in full or in part, in the book itself); id. at $40-41,86,90,147,153$ (providing facsimiles of such texts); BROWN, supra note 72, at 40 (stating the privilege's inclusion was not yet a "customary feature ... at a time when title pages ... were still in development"); id. at 51 (explaining Lemaire was one of the first writers to include the entire text of his privilege prominently at the beginning of his book); Davidson, supra note 6 , at 607 (summarizing Lemaire's privilege). Including the full text of his privilege in the front of his book marks "Lemaire's strong defiance of other printers" and reflects "a greater need to warn printers of the author's rights as original owner to his work. ..." BROWN, supra note 72, at 51.

131 This approach contrasts sharply with the earlier medieval norm of creative work being a collective product. See BROWN, supra note 72, at 63-66. In Lemaire's time, too, even for written work, collective efforts were common. See, e.g., Woodmansee, supra note 71, at 27 (describing Renaissance "commonplace books," in which an individual copied excerpts from favorite written work interspersed with his own original writing). In England in the 1730s, visual artist William Hogarth was considered quite the rebel for taking the same approach Lemaire did in 1509 for similar reasons. See Liemer, supra note 100, at 14, 17 (describing Hogarth's control over his work and his involvement in the passage of the Engravers Act, 8 Geo. 2, c. 13 (1735) (Eng.)). The collective approach to creative work currently is making a comeback thanks to another technology shift that enables blogs, wikis, and social networking.

132 See BROWN, supra note 72, at 44-57 (reporting some of the patrons Lemaire produced works for at various times in his career). 
else who had invested capital in the printing business as a full-time occupation. ${ }^{133}$ In other words, Lemaire was both well-enough connected and doing well-enough financially to protect his work, ${ }^{134}$ that is, to protect both his economic and non-economic interests in the work.

Most printers would primarily have had an economic interest in a printed work. They were craftsmen and merchants, ${ }^{135}$ and for them quality control would only be a means to more income. Unauthorized printers, ${ }^{136}$ out to make a quick profit before the market for a new book was saturated, would have even less concern about quality control than authorized printers. But a writer like Lemaire, intent on maintaining connections to the royal court, would want his writing to be well-received in elite social circles. ${ }^{137}$ And so Lemaire likely had the same reaction most writers today have when their name is on a work that does not accurately represent their efforts. He would have been concerned about his public reputation, ${ }^{138}$ not just the income from the sale of books. To

133 Professor Armstrong points out that "[i]t is improbable that any author who desired a privilege for a new work of his, and could afford to pay for the grant, was refused," ARMSTRONG, supra note 89, at 204 (emphasis original), suggesting a writer did need some money up front to obtain a privilege. The costs could include payment to a lawyer or scribe to write out the text of the privilege and the standard fee to have a document read and signed by the appropriate royal court or law court official.

134 See, e.g., id. at 80-81 (describing instances of some writers financing the printing of their work, but as "a minority of those who obtained privileges"); id. at 182 ("Of living creative writers, those who obtained privileges were those best able, by the position in society which they occupied, ... to defend their interests.").

Only about $5 \%$ of the 7,719 known titles printed in Paris between 1505 and 1526 received privileges. See id. at 78. Many religious books like Bibles and hymnals did not qualify for printing monopoly privileges, see id. at 165, and the novelty, expense, and lack of access prevented many writers from seeking privileges, see $i d$. at 202-04.

135 See id. at 36 (describing Le Noir as a "university printer and bookseller"); id. at 129 (mentioning the "hand-to-mouth existence" of most printers). Over time Le Noir's name appears less frequently as the defendant in lawsuits and more frequently as a privilege holder himself, which suggests he caught on to the benefits of privileges and improved his circumstances. See id. at 36, 214-95.

136 Note that the meaning of "unauthorized" in this context literally means "not approved by the author." Thus the very term "to authorize"-_auteuriser"-refers to an author's ability to control his work.

137 Lemaire did manage his career successfully, and in 1512 secured an appointment as the Queen's historiographer. See ARMSTRONG, supra note 89, at 80 (describing Lemaire by that time as "a man of fame and wealth"); id. at 102 (describing Lemaire as "the most famous Frenchlanguage author of the period").

138 Another contemporary's request for a privilege stated an unauthorized printer could cause "very great prejudice and damage" - " "tres grant prejudice et dommaige," "-showing these writers did seek to protect their reputations. Id. at 80-81 (trans. the author). In their requests, they gave other non-economic arguments for deserving printing privileges, including the time and skill they had given to their works, and their desire to benefit the public, scholars, students, or the government. Id. at 82-83. 
have his written words presented to the public in an erroneous form was likely a personal affront. ${ }^{139}$

La Vigne, Lemaire, and a handful of others were known as les rbétoriqueursliterary writers who wrote poetry, accounts of current and historic events, and morality lessons--in the vernacular French. ${ }^{140}$ In her study of the still-existing copies of les rbétoriqueurs' manuscripts and books, Professor Cynthia Brown describes a variety of ways in which these authors transitioned from manuscript practices to print. ${ }^{141}$ For example, the practice of hiding a coy acrostic in a manuscript text to remind a wealthy patron of the writer's name gradually gave way to displaying the writer's name prominently on the title page of a printed book, for a wider reading audience to remember. ${ }^{142}$ Instead of a manuscript's hand painted picture of the patron's coat of arms, these writers began to include an engraving of their own pictorial symbol or coat of arms. ${ }^{143}$ Professor Brown concludes that these writers used these new strategies to assert themselves quite purposely. 144 She also notes that "the advent of print greatly facilitated the discovery of unauthorized textual appropriation by one's contemporaries."145

139 See BROWN, supra note 72 , at 48 (providing excerpts from a letter Lemaire wrote saying that such errors did annoy him); id. at 23-28 (providing excerpts from letters of the writer Bouchet complaining about changes to his work and its effect on his honor); see also Liemer, supra note 11, at 49 (explaining that the right of attribution protects authors from "a harm peculiar to creative endeavors").

140 See BROWN, supra note 72, at 14 (describing les rétoriqueurs as "poet-historians" whose work "constitutes the only consequential body of French vernacular literature that spans.... the transition from manuscript to print, ... approximately . . 1460 to 1530 ').

141 See id. at 6-7 (summarizing evidence of "an increasing use of self-promotional strategies, such as more author-centered images, more prominently publicized names, more directly accessible signatures, and a more author-identified narrative voice").

142 See, e.g., id. at 153-95 (providing details and facsimile examples of the transition); id. at 11 (explaining "the absent reader was becoming more and more a part of their strategy of address"); id. at 15 (summarizing the growing importance of displaying a writer's name on the title page). Although signatures were not required on French legal documents until 1554, Henri II, Ordonnance de Fontainebleau (Mar. 1554, recorded Oct. 1555), some of these earlier writers had appointments as royal secretaries and so were used to signing papers for their patrons. See id. at 153-54 n.2.

143 See id. at 99-151 (detailing the changes of writers' images included in their books and providing facsimile examples); id. at 157 (" $[\mathrm{T}]$ he growing effort of . . . writers to spell out their own names unambiguously when incorporating them into their texts reflects their gradual refusal to hide behind the names of their patrons and parallels their search for ... greater validation as literary creators.").

144 I present here evidence of a sustained effort on the part of vernacular writers to protect their works through lawsuit, the use of privileges ... and the supervision of their publication and distribution as early as the first decade of the sixteenth century. As a conscious and concerted move to control the destiny and public inauguration of their works, these forms of protection implicitly questioned existing patterns of publication behavior that often ignored authors' relationship to their writings after those writings left their 
French writers came to appreciate their new role in the economics of printed books of necessity, at a time when patrons in France happened to be increasingly hard to find ${ }^{146}$ and a few particularly aggressive, unauthorized printers enjoyed the benefits of the new, totally unregulated printing industry. ${ }^{147}$ Literary writers, however, were not yet able to survive on the income from selling copies of their printed books, even if they secured a privilege for an initial edition, and they continued to seek patrons for their work. ${ }^{148}$ During this transitional time period from manuscript to print, literary writers were functioning in two modes: ${ }^{149}$ one mode depended on the courteous exchange of gifts with patrons ${ }^{150}$ and one mode depended on selling books to the public. ${ }^{151}$

hands. They also expressed writers' recognition of their inherent rights to their own words, at least during the first stages of publication, and their attempt to impose this consciousness on other participants in textual production.

Id. at 3. While serving sometimes as publicists or propagandists for their patrons, these writers learned to "promote their [own] identity and authority in print for the sake of protecting their writings," id. at 11, "reshaping... propagandistic modes into self-advertisement," id. at 14. Professor Brown even likens Lemaire's strategy of printing his own work to the king's propagandist strategies, as both sought to broaden their public support. Id. at 47 . Through writers" lawsuits and the inclusion of their privileges in their books, "the author had acquired a new, publicized legal status." Id. at 38.

145 Id. at 31.

146 See id. at 14 (stating that this generation of French writers had less patron support than their predecessors). By way of example, just a few years after La Vigne was appointed secretary to King Charles VIII, his patron died; the evidence suggests he had no patron when he brought suit in April 1504, half a year before being appointed the Queen's secretary. Id. at 18, 90, 106.

147 Professor Brown suggests that the most aggressive early printers actually stimulated the writers' creativity and their defensive reactions. See id. at $6-7,189$.

148 See, e.g., id. at 12 (contrasting the greater financial security with a patron and the greater "freedom of expression" without a patron); id. at 46 ("Although intent upon obtaining economic security through patronage... Lemaire seems above all to have desired creative independence ...."); id. at 145 (describing "the weakening spirit of the gift economy around this time, attributable both to the growing influence of the market economy and to increasing pressures of obligation').

149 See id. at 13 ("As in most transitions, old and new systems coexisted for some time."); id. at 44 (explaining that the writer Lemaire "[w]hile trying to get his foot into the noble entryway of the house of France ... was also attempting to gain more widespread public recognition,...."); id. at 107 (referring to "the intersection of the world of the gift and the world of the marketplace"); id. at $107 \mathrm{n} .11$ (quoting Natalie Z. Davis, Gifts, Markets, and Historical Change in Sixteenth Century France, in ODYSSEUS-92: MAN IN HISTORY, HISTORIAN AND TIME 3-4 (1994) (reporting "the possibility of moving back and forth between the gift mode and the sale mode, while always remembering the distinction between the two registers." ")); $i d$. at 151 (noting "the author's struggle to redefine and publicize an increasingly independent status while continuing to utilize and depend on the patronage system"); id. at 243 (referring to "the conflicting needs of late medieval authors, who were striving for a certain literary independence while still remaining dependent on the financial support of nobles.").

150 At times even the relationship between writer and patron was "double-edged," both a "service-oriented, gift-exchange" relationship, and a "developing commercial relationship 
These writers retained a heightened appreciation of honorable conduct ${ }^{152}$ and a habit of exchanged signs of respect from manuscript practices. And so in the earliest days of printing in France, literary writers took steps to protect interests in their work that reflected both the economic and non-economic value of their work. Both resources and circumstances allowed-and indeed forced-these writers to assert what are now the rights of disclosure, attribution, and integrity.

The ability of some French authors like La Vigne and Lemaire in the early 1500 s to assert creative control over their work is likely the first instance of the inclusion of both economic and non-economic interests in French intellectual property considerations. Their assertions of authorship occurred as a small, isolated cluster of early cases and privileges, arising as interests related to the new technology of printing were still being sorted out. The practice of seeking a privilege for the initial printing of a work became common in France in less than a decade, ${ }^{153}$ suggesting it was a very practical solution for writers wanting and able to protect their works and their reputations.

In some sense these authors were like their ancient Roman counterparts. They had public stature to protect. ${ }^{154}$ A specific relationship-a relationship with the monarch, royal court, or local noble family-was important to allow them to protect their works of authorship. ${ }^{155}$ But maintaining that human relationship to stay in line with social norms was no longer their primary motivation; using that human relationship to gain a privilege and protect their personal relationship to their creative work, to protect their authorship, was the new focus. ${ }^{156}$

between writers and their sponsors." BROWN, supra note 72 , at 110 . This dynamic foreshadows the double bind of the playwrights of the Comédie-Française, infra p. 97.

151 See BROWN, supra note 72, at 6 (referring to "the public's awareness and recognition of increasing authorial concern for literary property and propriety" and "a growing consciousness on the part of the public and the writer of the author's more prominent role in the literary enterprise and society itself"); id. at 57 (suggesting Lemaire understood the need "to sell "himself" to sell his work, as his "new awareness of the text as commodity ... translated into his self-presentation in the narrative").

152 Indeed, les rhétoriqueurs were so named because they frequently used allegorical rhetoric to encourage honorable conduct and morality.

153 See ARMSTRONG, supra note 89, at 206.

154 See infra pp. 86-88.

155 See infra pp. 86-88.

156 Inevitably economic and non-economic interests in creative work intertwine, see Liemer, supra note 11 , at 55-56, and these writers did protect their economic interests. After all, "the privilege was essentially a commercial monopoly. ..." ARMSTRONG, supra note 89, at 164 . And "each writer's actions reflected a new level of concern regarding authorship, bearing upon economic as well as moral issues." BROWN, supra note 72 , at 32 .

There are some surviving texts of written agreements between writers who held early printing privileges and their publishers, and eventually written agreements between publishers who held printing privileges and other publishers. By the 1540 s, printing privileges were included 
By 1532, the well-known Renaissance writer Clement Marot complained directly to readers, in outspoken terms, about errors that profited printers at the expense of a writer's honor. ${ }^{157} \mathrm{He}$, too, was concerned about misattribution, and he stated in the front of authorized books that these were not the editions into which other people's work had been inserted. ${ }^{158}$ Marot was articulating the value he placed on non-economic interests in his work, the ways in which the work reflected on his artistic reputation. Le droit moral protects against such abuses.

Significantly, authors themselves brought the first intellectual property law suits and received the first printing privileges in France, allowing consideration of author-centric concerns about the creative process as the law developed. These concerns included control over the creative process and its impact on the author's reputation, not just economic interests. ${ }^{159}$ Also significantly, these law suits and printing privileges occurred when printing was still a new, unregulated industry. 160 True, these early assertions of authors' rights did not start an

in book ownership transfers and licensing deals, see ARMSTRONG, supra note 89, at 191-94, evidence of the growing economic value of a printing privilege.

157 See ARMSTRONG, supra note 89, at 204 n.2 (citing Clément MARot, Les EPItres (C.A. Mayer ed., 1958)). Marot published a few works without the benefit of a privilege. Then, in the preface of the first book for which he received a privilege, he complained of "the displeasure that I have had in having published and cried throughout the streets a large part, entirely incorrect, poorly printed, and more for the profit of the bookseller than for the honor of the author"_- "le desplaisir que j'ay eu d'en ouyr cryer et publier par les rues une grande partie, toute incorrecte, mal imprimée, et plus au proffit du Libraire qu'à l'honneur de l'Autheur.'" Id. (trans. the author). Marot also was among the first to use the term "contrefaicte"-_counterfeit"-to refer to pirated copies. See BROWN, supra note 72 , at 252-53. Despite the prevalence of book privileges in his time, writers still had to rely on the honesty of printers in far-flung cities. Id. at 251.

In 1545, Venice enacted a law to require a writer's consent to a printer's copyright, causing many writers to go to Venice to find printers. Their books were sold throughout Europe, and readers became used to seeing both printers' and writers' privileges printed in the books they bought. See Prager, supra note 34, at 135.

"By the 1550's, ... not only did the poet Pierre de Ronsard obtain a perpetual privilege ... but royal grants stated that authors best oversaw the publication of their own works." BROWN, supra note 72 , at 59 . The mid-sixteenth century was also when literary writers began to include individualized portraits of themselves in the front of their books, showing the further rise in the importance of a writer's identity. Id. at 102-03.

158 See BROWN, supra note 72 , at 253 (noting that "the author ... had to continue waging the battle for his rights, his readers becoming the jury").

159 In sharp contrast in England, when the earliest intellectual property lawsuits appeared some two hundred years later, printers sued printers, practically guaranteeing the economic interests of the new mercantile class would prevail over the non-economic interests of writers. See Liemer, supra note 100.

160 See ARMSTRONG, supra note 89, at 35 ("It was a new craft, without restrictions or regulations. Anyone could set up a press. Anyone could finance or sell printed books."); id. at 117 ("At this period, application for a book-privilege was a request for a favour, not compliance with a law.").

As printing developed and required new terminology, the term that eventually arose in 
unbroken line of legal developments leading straight to le droit moral.161 As the printing industry developed further, French printers came to have more economic power than writers, and regulations came to favor printers, in part to aid government censorship. ${ }^{162}$ Nonetheless, much in the same way Michelangelo made a visual artist asserting his rights something the Western world had at least heard of, in the same time period these early lawsuits and privileges made protection for the non-economic interests in a creative work something heard of in France. ${ }^{163}$ The coincidence of printing being too new to regulate and some writers pro-actively seeking protection for their work contributed to the French ability to conceive of authors asserting their creative interests in their work. ${ }^{164}$

Privileges in books "probably brought this way of seeking protection to the attention of artistic and technical craftsmen who might otherwise not have thought of it."165 Some books containing only maps, illustrations, calligraphy fonts, and music received privileges, and then those types of individual items did, too. ${ }^{166}$ In this way, the idea of controlling the presentation of their creative work, by controlling its publication, began to expand to some visual artists and music composers. ${ }^{167}$

France was te droit d'auteur, literally "the author's right." Originally this term did refer specifically to writers, then gradually it came to refer to intellectual property rights more generally. See, e.g., Anne Latournerie, Petite bistoire des batailles du droit d'auteur, http://lasectionnumeriquedups.net/pe tite-histoire-des-batailles-du-droit-d'auteur/ (Dec. 15, 2001) (acknowledging the term clearly refers to a work's creator).

161 See ARMSTRONG, supra note 89, at 207 ("But the author's privilege was a step in the right direction."); BROWN, supra note 72, at 254 ("[T] he seeds of authorial rights had been planted.").

162 Regardless of whether a monopoly printing privilege was involved, starting in 1521, University of Paris officials were supposed to approve all new books, with the Faculty of Theology assigned to approve all books on religious topics. See ARMSTRONG, supra note 89, at 100,110 (referring to Francis I's order of March 18, 1521). Starting in 1566, before being printed, all new books were required to have permission granted under the toyal seal, the beginning of a licensing scheme that lasted until the French Revolution. See id. at 100 (referring to Article 78 of the Edict of Moulins by Charles IX).

163 See BROWN, supra note 72, at 59 (asserting that "recognition of the crucial role played by late medieval poets in the institutionalization of their rights as writers is long overdue").

164 In 1537, French King Francis I issued a law "requiring the deposit of books and other cultural materials in a library for the purpose of preservation." Menell, supra note 52, at 1020-21. Thus the French preserved the originals of texts and related arts, while accounting for the broader national interest in what was gradually becoming intellectual property. As in ancient times, by preserving works in their original form, the French deposit requirement protected the integrity of each work, in effect protecting the author's right of integrity. Deposit requirements are now common around the world, including in the United States. See 17 U.S.C. $₫ 407$ (2006).

165 ARMSTRONG, supra note 89, at 205.

$160 \mathrm{Id}$.

${ }^{167}$ A similar expansion from protecting texts to protecting other types of creative work also occurred in the history of Anglo-American intellectual property law. See Liemer, supra note 100, 
With Michelangelo and Dürer establishing international individual artistic reputations, the guilds valuing individual contributions, French literary writers obtaining privileges and asserting their creative interests in court, and readers seeing writers' privileges acknowledged in books, concepts about creative work and the people who produced it changed dramatically in the first half of the sixteenth century. ${ }^{168}$ Protecting the creative expression of an individual person became a known value. ${ }^{169}$ A culture that could develop le droit moral was emerging in France. ${ }^{170}$

\section{LA COMÉDIE-FRANÇAISE}

When Margaret Mead said a small group of thoughtful people could change the world, ${ }^{171}$ she probably was not thinking of the playwrights of the ComedieFrançaise during the ancien régime. As French book publishing gradually came to be a highly regulated mercantile field, ${ }^{172}$ intellectual property law in France

at 33,35 .

168 See Brown, supra note 72 , at 33 \& $\mathrm{n} .18$ (explaining the transition from a focus on the uniqueness of a specific handmade work to the uniqueness of a specific writer); Prager, supra note 34 , at 137 (describing also the importance of " $[t]$ he undercurrent of popular opinion" in this time period).

169 "By 1554 it was being stated in royal grants that wrong was done to an author by unauthorized and incorrect printing of his works, ...." ARMSTRONG, supra note 89, at 83-84. Note that this acknowledgment occurred a century and a half before John Locke published his ideas about natural law allowing a person to enjoy the fruits of his labor. See John Locke, $A n$ Essay Concerning the True Original, Extent, and End of Civil Govemment, in JOHN LOCKE, Two TREATISES OF GOVERNMENT 184-202 (1698) (facsimile ed., 2010).

170 Although book printing privileges originated in Italy and spread throughout Europe, the early system worked particularly well in France. It was a relatively large geographic area under one crown, requests were handled without favoritism, privileges usually were granted only for work being printed for the first time, and privileges on average lasted only three years-enough time to sell a first printing without tying up trade indefinitely. See ARMSTRONG, supra note 89, at 206 nn.1-3.

171 See Frequently Asked Questions About Mead/Bateson, THE INSTITUTE FOR INIERCULTURAL STUDIES, INC., http://www.interculturalstudies.org/faq.html\#quote (last visited Sept. 28, 2011) (explaining the uncertainty of the exact origin of Mead's comment).

172 See Geller, supra note 69, at 216 (explaining that in seventeenth century France, the Crown, "[w]ith the complicity of the Paris Book Guild,... increasingly policed the book trade."); id. at

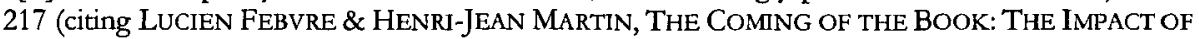
PRINTING 1450-1800, at 241 (Geoffrey Nowell-Smith \& David Wootten eds., David Gerard trans., 1976) (stating that for the book trade in France, "royal and trade regulations proliferated into 'a vast mass of often conflicting legislation' ")). The further development and regulation of the French printing industry lies beyond the scope of this Article. For a broad overview, see Latournerie, supra note 160, at 2-4; Jane C. Ginsburg, A Tale of Two Copyrights: Literary Property in Revolutionary France and America, 64 TuL. L. REv. 991, 997 (1989-1990) (summarizing the prerevolutionary regulatory scheme for printed texts); SAUNDERS, supra note 5, at 83-89 (reviewing the pre-revolutionary privileges and regulations for printed texts); see also generally CARLA HESSE, 
could have developed as it did in the United Kingdom, eventually foreclosing all development of le droit moral.173 The playwrights of the Comédie-Française, however, were working under a different regulatory scheme than the writers of other texts. This regulatory scheme created unique processes and unique concerns for the playwrights. Professor Gregory Brown has written a detailed sociological study of the Comédie-Française playwrights of the ancien régime. ${ }^{174}$ Examining his historical sociology for clues, I see true origins of $t e$ droit moral. I posit that it was the Comédie-Française playwrights, with their very particular, heightened need to assert their honor and reputations, who made it possible for non-economic interests in creative work to become more fully recognized by French law.

The Comédie-Française was founded in $1680^{175}$ and received a royal monopoly to perform plays in French in Paris. ${ }^{176}$ The troupe of twenty-four actors ${ }^{177}$ performed upon request for the king and his royal court at the palace in Versailles, and they performed nightly for the public at their theater in Paris. ${ }^{178}$ The Comédie-Française became-and remains-the pre-eminent theater in France, ${ }^{179}$ and many of the greats in the French literary canon wrote plays specifically for this theater. ${ }^{180}$ In the seventeenth and eighteenth

PUBLISHING AND CUltURAL. POLITICS IN REVOLUTIONARY PARIS, 1789-1810 (1991).

173 See Liemer, supra note 100, at 9-32 (analyzing why moral rights did not develop when British intellectual property law did).

174 Gregory S. Brown, A Field of Honor: Writers, Court Culture and Public THEATER IN FRENCH LITERARY LIFE FROM RACINE TO THE REVOLUTION (2005).

175 See Histoire et patrimoine: Il était une fois, COMEDIE-FrANCAISE.FR, http://www.comedie-franc aise.frhistoire-et-patrimoine.php?id=526 (explaining the theater mergers that resulted in the Comédie-Française in 1680); Charles VARLET DE La GRANGe, Le REgistre de LA Grange (1658-1685) (Bert Edward Young \& Grace Philputt Young eds., facsimile ed., Droz 1947) (providing a daily log of Molière's acting troupe when it merged with others to become the Comédie-Française).

176 Histoire et patrimoine: Auteurs et repertoire, COMEDIE-FrANCAISE.FR, http://www.comedie-fran caise.fre/histoire-et-patrimoine.php?id $=525$ (last visited Sept. 28, 2011) (explaining the monopoly extended to Paris and its suburbs).

177 Unlike the Globe and other contemporary British theaters, the Comédie-Française had both male and female actors. See generally Lenard R. Berlanstein, Women and Power in Eigbteenth-Century France: Actresses at the Comédie Francaise, 20 FEMINIST STUD. 475 (1994).

178 See Brown, supra note 174, at 11 (describing the Comédie-Française as "an institution at once royal and public').

179 See Histoire et patrimoine: comédiens, COMEDIE-FRANCAISE.FR, http://www.comedie-francaise. fr $/$ histoire-et-patrimoine.php?id $=524$ (last visited Sept. 28, 2011) (referring to the ComédieFrançaise as "la 'troupe unique du ni' Louis XIV"-the only theater troupe of King Louis XIV, the great arts supporter); BROWN, supra note 174, at 347 (stating the Comédie Française held "the central position in Old Regime literary life").

180 See Histoire et patrimoine: Auteurs et repertoire, COMEDIE-FRANCAISE.FR, http://www.comedie-fr ancaise.fr/histoire-et-patrimoine.php?id=525 (last visited Sept. 28, 2011) (listing the playwrights whose work has been performed the most by the Comédie-Française since 1680 , including 
centuries, the stage was the broadcast medium of the day, and Parisians commonly attended theater and opera performances several nights each week. At the theater one could see and be seen, ${ }^{181}$ find out the latest social and political news from other audience members, and hear the perspectives of the country's leading dramatists, ${ }^{182}$ all while being entertained.

Because of its prominence in Paris and its influence nationwide, the Comédie-Française was one of the many aspects of French life controlled by Les Premiers Gentilhommes de la Chambre du Roi, the First Gentlemen of the Royal Bedchamber. ${ }^{183}$ These four gentlemen were usually close male relatives of the king, literally trusted in his most inner chambers. ${ }^{184}$ Two of the gentlemen were assigned oversight of all the theaters and the opera, with one of those focusing on the Comédie-Française. ${ }^{185}$ Loosely analogous to today's political appointees who direct federal administrative agencies, they were like the chairmen of the Federal Communications Commission and the National Endowment for the Arts of their day. Unlike today's executive appointees, these gentlemen were French nobles, and it was not in keeping with their social station to report to work every weekday morning. Instead, they developed regulations ${ }^{186}$ and positioned intermediaries to keep control over their assigned industries, ${ }^{187}$ minimizing the occasions on which they had to intervene personally.

A highly detailed set of regulations evolved for the Comédie-Française. ${ }^{188} \mathrm{It}$ was a repertory theater, meaning a set group of actors learned and performed the plays chosen for a theater season. ${ }^{189}$ The actors chose the scripts they

Molière, Corneille, Voltaire, and Hugo).

181 See BROWN, supra note 174, at 50 (reporting that "the Comedie-Française became one of the crucial sites in which elites publicly displayed their prestige and power..."); id. at 116-17 (describing the development of box seats for this purpose).

182 See id. at 73 (acknowledging the playwrights' role in the development of Enlightenment ideas).

183 See generally Hubert Cole, First Gentt Eman of THE BedCHAMber (1965). Any resemblance this title bears to the work of Monty Python may not be entirely coincidental.

184 See Maison Civile du Roi: La Cbambre du Roi, COUR-VERSAILLES.FR, http://cour-versailles.fr/L aChambreduRoi.aspx (last visited Sept. 28, 2011) (providing information on appointments and staffing in the French royal household).

185 See BROWN, supra note 174, at 509 (reporting the First Gentlemen held primary authority over the theater from 1689 until October 1789, when they ceded authority to the municipality of Paris during the French Revolution).

186 See id. at 49 (reporting the gathering of earlier orders into the first set of regulations in 1697).

187 See id. at 78 (reporting that a committee of the actors was created in 1762 to manage the theater and a committee of lawyers was created in 1765 to enforce the First Gentlemen's orders).

188 See id. at 77-81 (describing the regulatory process and the regulations' focus from 1680 1751).

189 See Histoire et patrimoine: Auteurs et repertoire, COMEDIE-FRANCAISE.FR, http://www.comedie-f rancaise.fr/histoire-et-patrimoine.php?id $=525$ (last visited Sept. 28, 2011) (describing the repertoire of the Comédie-Française, which is archived in the company's La Grange database). 
performed, ${ }^{190}$ so a playwright had to procure a meeting with the troupe and read his play to the actors, and then they voted on whether to accept the play. ${ }^{191}$ The actors and the playwrights both were paid from the box office receipts, ${ }^{192}$ and a play ran only as long as it was profitable. ${ }^{193}$

In France at that time, noblemen pursued the arts as a pastime, and some educated noblemen wrote for the theater. ${ }^{194}$ As a member of the highest echelon of society, a nobleman would have an easy time arranging meetings with the troupe, for the required preliminary reading and vote, and for other discussions about edits, scheduling, and casting. The troupe would naturally show polite deference to a member of the royal court. A nobleman also would not likely jeopardize his social standing by pushing the envelope in terms of subject matter or style. Indeed, he likely would not want to be seen as taking his work in the arts too seriously; it was acceptable as a pastime, not as a job.

Most of the playwrights, however, were not noblemen. They typically were from upper middle class or professional families. ${ }^{195}$ They often were young men from the provinces with solid educations, who ventured to Paris to make a name for themselves. ${ }^{196}$ To be introduced to the acting troupe, they first had to

Once performed by the actors, a play entered the repertoire permanently, a practice still followed. See id. (explaining the practice by which a play enters the permanent repertoire).

190 Unintentionally, "the royal actors came to function as gatekeepers, controlling access to the revenue and prestige generated by the theater through their selection of plays for performance." BROWN, supra note 174 , at 49.

191 See id. at 82 (explaining the process of accepting a play). Despite the theater's name, both tragedies and comedies were performed, on alternating nights, allowing the actors to explore a wide range of subject matter. See $i d$. at 95-98 (explaining factors that contributed to the selections in the repertoire).

192 See id. at 111-17 (describing the evolution of the ways in which the author's share was calculated).

193 See id. at 98 (reporting the importance of the day of the week that a new play opened, so it could have a big enough crowd to merit future performances); id. at 212-14 (describing the process by which plays fell from the performance schedule). Many plays had a run of only a few nights. Le Barbier de Séville, quoted at the beginning of this Article, was considered widely successful when it ran for thirty-two performances. See id. at 195.

194 See id. at 69, citing Robert Darnton, The Facts of Literary Life in Pre-Revolutionary France 270-80, in The Political. Culture of the Old Regime 261, 270-80 (Keith Michael Baker ed., 1987) (reporting a small number of noblemen writing for the Comédie-Française in the season studied, 1776-1777).

195 See BROWN, supra note 174, at 69 (reporting that the most common background for the Comédie's playwrights in the 1776-1777 season was "non-noble legal, financial, or administrative families").

196 See, e.g., id. at 54-61 (relating Voltaire's rise from the son of a notaty to a Comédie-Française playwright to an autonomous literary star). "The Comédie ... became, ... definitively, the locus of efforts by aspiring writers seeking to establish themselves as men of letters at court, among elites, and before a growing commercial audience for theater throughout the kingdom." Id. at 50 . Many people who tried to become Comédie-Française playwrights were not successful. See id. 
become known to high society and secure a patron or two. ${ }^{197}$ A playwright needed the support of a respected noble to have a script read and accepted by the troupe of actors. ${ }^{198}$ A noble's support was also helpful in gaining approval for the script from the official police department censor and the member of the First Gentlemen overseeing the Comédie-Française. ${ }^{199}$

To make himself acceptable to the nobility, a playwright had to mirror the manners and ways of the noble class. ${ }^{200}$ Striving to get ahead was not how nobles behaved. Thus a young playwright had a difficult maneuver to perform, asserting himself enough, in the limited acceptable ways, to become known in elite social and artistic circles, without appearing to be striving to get ahead at all. ${ }^{201}$ Historical sociologists have referred to this position as a double bind.202 In this double bind, as a playwright mimicked the ways of the nobility, he had to protect his public reputation at all costs. ${ }^{203} \mathrm{He}$ had to behave as un bomme

at 11 (describing "frustration, rejection, and public humiliation by the troupe, theater audiences, elites at court, other writers, and the press").

A small number of women wrote shorter, one-act plays that started an evening's entertainment, usually on the less important nights of the week. See id. at 71-73 and accompanying footnotes (providing data on eighteenth century French female playwrights).

197 See, e.g., Frank D. Prager, An Award and a Law Obtained by Caron de Beaumarchais, 44 J. PAT. OFF. SOC'Y 147, 147-50, 165-69 (describing how Beaumarchais first came to the attention of the aristocracy as an innovative watchmaker).

198 See BROWN, supra note 174 , at 6-7 (stating protection from elites allowed authors to create); id. at 62 (stating "between 1715 and 1750 most new and aspiring dramatic authors were... subordinate in their direct encounters with both troupe members and the urban elites that the actors took to be their primary audience').

199 See, e.g., id. at 238-40 (describing the evolution of the censorship process for ComédieFrançaise plays); id. at 211 (stating that "the censor's power depended... on his own status relative to that of the writers"); id. at 262 (stating that playwrights expected censors to recognize playwrights' status); id. at 238-39 (explaining the interplay between the police censor and First Gentlemen). For the censorship of printed books, too, "the boundary between legal and illegal publications was never absolute nor permanent." Daniel Roche, Printing, Books and Revolution, in Publishing and READERSHIP in ReVolutionARY FRANCE AND AMERICA 1, 5 (Carol Armbuster ed., 1993).

200 See BROWN, supra note 174, at 17 (describing these writers as operating within royal court culture, including "the norms, language, hierarchies, and practices of elite sociability").

201 See id. at 4 (describing "the tension between cultural expectations of self-restraint and social, economic, and even psychological imperatives for self-assertion").

202 See id. at 30-31 (explaining the concepts of the double bind and "established outsiders"); id. at 11 (describing these writers as "case studies of cognitive dissonance").

203 After committing a social faux pas, a savvy playwright would even remove himself from Parisian life for a respectable amount of time, to show his contrition and rehabilitate his reputation. See, e.g., id. at 58 (describing Voltaire's self-exile to London in 1726). It was almost a badge of honor for a playwright to land in prison for a short time, see, e.g., id. at 58 (referring to Voltaire's "brief imprisonment"); id. at 144 (reporting Beaumarchais's imprisonment while $L$ Barbier de Séville awaited performance). A few days in the Bastille (with a pen, some paper, and a writing table to petition a patron for release) might cause the town to talk, but handled gracefully 
bonnête, a man of courtly honor. ${ }^{204}$ Failure to do so could put an end to his literary career. ${ }^{205}$ As Professor Gregory Brown explains, in this context "status was as much a currency ... as money or favors."'206

Thus, for over 100 years, a playwright wanting to mount his work in the preeminent theater in Paris, the city that was the cultural epicenter of Europe at the time, had to be as concerned with maintaining his honor and reputation in elite social circles, and as concerned with the process of moving his work into the repertoire of the Comédie-Française as he was with the writing process itself. Protecting his honor and social reputation became an integral part of the creative process for a Comédie-Française playwright in the ancien régime. ${ }^{207}$

Over time, as monarchs changed and the playwrights discussed day-to-day concerns with actors from the troupe and their overseer from the First

would not necessarily have a negative career impact. See id. (reporting the censor's own imprisonment after Beaumarchais's release). In contrast, Beaumarchais's later imprisonment at the age of fifty-five, in a suburban boys' reform school, was meant to bring the disgrace that it did. Id. at 299-308 (describing the arrest, its social context, and its consequences for the writer).

204 The playwrights had to "demonstrate personal virtue" and use "their status and virtue to serve a cause larger than themselves, rather than for self-interest of any sort, which would have destabilized the entire court society and the kingdom over which the court ruled." Id. at 19. "[A] writer not accepted by the Parisian elites . . could not be considered honorable." Id. at 66.

The actors did not always display a courtly demeanor when playwrights presented their work to the troupe. The writers complained so consistently that the First Gentlemen had to write regulations requiring the actors to behave civilly to the writers. See id. at 85, 92-93.

$205 \quad[\mathrm{~A}] \mathrm{n}$ author without legitimacy ... . could be easily dominated or simply ignored by other participants in literary life, such as potential protectors, other writers, royal officials and censors, the press, and the commercial public. An author who had established personal legitimacy could expect . . . the civility and respect Id. at 28 . due an bomme de lettres [man of letters]... .

A writer of a book also sought wealthy patrons, ideally one to help underwrite the work in progress and another to let the book be dedicated to him, a tacit endorsement that helped sales. The rypical book writer, however, also was concerned with maintaining a good working relationship with his printer and bookseller, members of the mercantile class interested foremost in earning profits. Playwrights often did receive income from publication in print of their work. See id. at 125-30 (explaining typical play printing schemes). But it reeked of desperation to print a play before its run in the theater finished. See id. at 126 (explaining that "printing an unperformed play implied a transgression by the playwright against standards of self-restrained comportment"). Waiting for a play to be performed before having it printed could mean waiting years to see any income from a play. See id. at 126-27.

206 Id. at 94. As Roscoe Pound stated in his groundbreaking article, Interests of Personality, 28 HARV. L. REV. 343, 349 (1915), "one's reputation is an asset as well as a part of his personality."

$207 S_{e e}$ BROWN, supra note 174, at 81 (explaining that the regulations managing interactions between the actors and playwrights assumed each would act in their self-interest, creating tensions for playwrights trying to disprove self-interest); id. at 90-93 (suggesting the playwrights were displeased with any regulations that made their work more commercial and less a matter of honor). 
Gentlemen, changes were made to the regulations. ${ }^{208}$ The playwright PierreAugustin Caron de Beaumarchais is credited with organizing the first writers' union, the Société des Auteurs Dramatiques (SAD), the Society of Dramatic Authors. ${ }^{209}$ But what Beaumarchais actually did was invite other ComédieFrançaise playwrights to meet over supper to discuss improvements to the regulations they worked under, before discussing those changes with their overseer from the First Gentlemen. ${ }^{210}$ As most people would, playwrights who negotiated to create the rules, and then complied with the rules, expected the rules' intended results, usually certain actions and treatment by others. Such expectations evolved into personal interests that the playwrights wanted to protect.

Consider the simple example of a child who has a bedtime routine. If a child agrees with his parents that he will brush his teeth and put on his pajamas, and then he can hear a bedtime story, the child comes to expect that proper behavior will lead to the promised result. A child who conforms appropriately but does not receive a bedtime story will be sorely disappointed (and likely let his parents know).

Similarly, playwrights who spent years exercising social self-restraint came to expect their proper behavior would lead to specific, promised results (in their case, rather than being read a story, the opportunity to tell a story). For a playwright who successfully followed the written regulations and the unwritten social rules, these expectations gradually strengthened into interests the playwright wanted to protect.

For example, one aspect of regulated behavior was the order in which the actors performed a season's plays. To reduce arguments between the actors and playwrights about whose play should go first, the First Gentlemen ordered the troupe to create three lists, one each for comedies, tragedies, and short pieces, ${ }^{211}$ listing the plays in the order they would be performed. These lists

\footnotetext{
208 In the second half of the eighteenth century, the Comédie-Française was performing new plays less frequently, even as more plays were being written. See id. at $240-42$ (providing statistics on the number of plays accepted and actually performed in the mid-1770s). The playwrights conveyed their concerns to the First Gentlemen, who overhauled the regulations several times. See id. at 77-79 (summarizing major revisions to the regulations).

209 See Historique, SACD, http://www.sacd.fr/Historique.31.0.html (last visited Sept. 12, 2011) (stating, on the official website of today's French writers' union, that it began when Beaumarchais organized a writers' meeting on July 3, 1777). For a differing account of the origin of today's Societé des Auteurs et Compositeurs Dramatiques (SACD), the Society of Dramatic Authors and Composers, see BROWN, supra note 174 , at 418-20.

210 The playwrights' attendance showed how frustrated they were by their situation, but the trajectory of this meeting was hardly pre-ordained. See BROWN, supra note 174, at 197-98 (reporting the meeting was initiated by the Duke de Duras, one of the First Gentlemen).

211 See id. at 97 (describing this regulation).
} 
then had to be displayed in the theater lobby, so everyone could keep track of any changes and a playwright could not secretly receive special treatment. ${ }^{212}$ There were both written and unwritten rules for acceptable behaviors by which an author could move his name higher up on a list, so his play would be performed sooner. ${ }^{213}$ The process often took years.

A playwright would naturally come to expect that following the rules and regulations would result in his play being performed sooner. He would have difficulty maintaining both his reputation and his income if his plays were not performed. So this expectation developed into an interest that the playwright wanted to protect and worked hard to protect. ${ }^{214}$ A playwright who became adept at influencing when his play would be presented was essentially learning to exercise what is now called the right of disclosure, le droit de divulgation.

There were other special prerogatives that the regulations gave the playwrights, which they came to expect, and which also evolved into interests they wanted to protect. For instance, once the troupe chose a play, the playwright chose the actors, casting the play. ${ }^{215}$ Deciding who would perform each part gave the playwright some artistic control over how his work was presented. Likewise, the practice of having the playwright participate with the actors in the script editing process and various staging decisions allowed the playwright to continue to maintain some control over his work and how it represented him. A playwright who became adept at the social relationships with the actors required to control these aspects of his work, working hard to maintain the integrity of his creation, was learning to exercise what is now called the right of integrity, le droit au respect de l'oeuvre.

Another important aspect of the regulated interactions between the playwrights and the acting troupe, "the fall," also helped the right of integrity develop. When a play stopped being profitable, it fell from the performance schedule, and it entered the permanent repertoire. ${ }^{216}$ The ability to profit from

212 Posters announcing the next day's play served a similar purpose. See id. at 105 . These practices were the origin of the theater marquee, which today announces upcoming plays or films.

213 See, e.g., id. at 97 (reporting the royal court's desire to see a play as one way to have it staged sooner); id. at 331 (reporting that plays particularly relevant to current events were staged sooner). Often to get ahead in the long term, a playwright disinterestedly ceded his place on the list in the short term. For the playwrights, trading their positions up and down the lists "was one of the most important strategies . . . in trying to use the Comédie Française to fashion a public identity." Id. at 98. Maneuvering through this process, "they drew directly from the culture of courtly civility, in which recipients expressed disinterest in the gift and denied having solicited it, while donors denied any expectation of direct reciprocation." Id. at 99.

214 See, e.g., id. at 271-313 (describing how, over many years, Beaumarchais worked to control when and where Le Mariage de Figaro appeared on stage and in print).

215 See id. at 103-04 (describing the casting regulations, efforts by actors to circumvent them, and playwrights' efforts to prevent circumvention).

216 See id. at 212-15 (explaining the process of a play falling from the performance schedule). 
that play in the future belonged to the acting troupe. ${ }^{217}$ If the play was revived, the playwright had no share in the box office take. ${ }^{218}$ But the troupe did not object to playwrights having their plays printed for sale, after the initial run of performances was over. ${ }^{219}$ And for revivals, the troupe brought playwrights back into the creative process, to participate again in editing, casting, scheduling, and staging. ${ }^{220}$ The Comédie-Française playwrights came to expect this continued control over their works in the repertoire, and the regulations came to protect these expectations. ${ }^{221}$ In this way, initial income from the work and continued control over its presentation were separated, creating different interests, one monetary and one personal.

Here is the likely origin of the attachment of le droit moral to the person who created the work, rather than to the work itself. Even after losing the ability to gain financially from a work in the Comédie-Française repertoire, the playwright retained the ability to exercise some control over his artistic expression. ${ }^{222}$ Similarly, today in France an author retains the ability to exercise control over his artistic expression after selling it, with his droit au respect de l'oeuvre-right of integrity. The eighteenth century playwright was essentially exercising the right of integrity separately from any ownership claim to income derived from the work, separating le droit moral, the moral right (protecting creative decisions and artistic reputation), and le droit patrimonial, the copyright (protecting income and commercial exploitation).

In addition, a playwright received free entrance into the theater, his droit d'entrée-right of entrance, which showed everyone in an appropriately low-key

\footnotetext{
217 Id.

218 Id.

219 See id. at 117 (differentiating playwrights' droits d'auteur and propriété littéraire from book printing monopoly privileges); $i d$. at 217 (stating "the troupe never sought a privilege for any edition of a play for which it held performance power after a fall" from the performance schedule); id. at 235-36 (distinguishing the book trade's commercial droit de copie and privilege from ComédieFrançaise practices).

220 See id. at 214-15 (explaining the process of a play being revived after it fell from the performance schedule).

221 See id. at 216 (reporting such regulations were issued in 1768, but rescinded six years later when Louis XVI's reign began); id. at 230 (explaining that when Beaumarchais petitioned the First Gentlemen for regulations protecting these interests again in 1780, he "sought neither patronage nor absolute property rights but recognition of the non-material, personal powers he called droits'). See generally Compte Rendu de l'Affaire des Auteurs Dramatiques et des Comediens Franfais (1780), available at http://www.copyrighthistory.org/cgi-bin/kleioc/0010/exec/showThumb/\%22f_178 $0 \% 22 /$ start $/ \% 22$ yes $\% 22$ (last visited Sept. 28, 2011).

222 Unlike printing privileges, " $[\mathrm{t}]$ he rights to the performed play ... were not transferable since they had been accorded to the person of the author." BRown, supra note 174, at 222. "Beaumarchais proposed an alternative idea of authorial property as a personal attribute, existing anterior to, and not dependent upon, the commercial exploitation of the work." Id. at 227.
} 
way that he was a Comédie-Française playwright.223 He also was entitled to a few free tickets for his friends, ${ }^{224}$ which had the practical effect of creating a visible entourage.225 Note how widely these indicia of status differed from the Lockean fruits of one's labor. 226 'The playwrights actively denied interest in the fruits so they could acquire these indicia of status. ${ }^{227}$

The playwright's share from the box-office income was referred to as the playwright's droits, in the sense of "what he was owed" or "what was due him"; his droits d'auteur were essentially earned royalties.228 But the various other prerogatives of the playwrights also were referred to as droits d'auteur, prerogatives due to the writer. ${ }^{229}$ These playwrights did not distinguish in their terminology the way the French terms droit d'auteur (copyright) and droit moral (moral right) do today; they developed a sense of entitlement to their income and prerogatives, all stemming from their work. They referred to all of these as proprieté. In their world, all those things due them because of their status as Comédie-Française playwrights were labeled with the same words. The concepts behind this terminology do not align neatly with modern American concepts of property rights (but, after all, property is a social construct). ${ }^{230}$

\footnotetext{
223 See id. at 105-08 (explaining circumstances causing this privilege to be limited or to be extended for a lifetime).

224 On opening night, a playwright's friends cheered the play, to help it stay in production. They were the original cabale, while audience members secretly organized to discredit a play on opening night were a claque. See id. at 505 (reporting the practices).

225 See id. at 108 (suggesting the playwright in this way temporarily appeared as a courtier).

226 See LOCKE, supra note 169, at 184-202.

227 See id. at 108 (describing playwrights who preferred entrance rights over royalties).

228 See BROWN, supra note 174, at 236 (explaining how the etymology of the English word "royalties" equates with the development of droits d'auteur as payments for uses of intellectual property).

229 See id. at 109 (describing these prerogatives as "a central component of their "droits d'autewr' "); id. at 109 n.206 (citing a 1777 reference to entrance privileges as " 'droits d'auteur" "); id. at 119 (stating concerns about these droits were worded in terms of "personal 'honor' "); id. at 218 (reporting playwrights' referring to the status markers attached to their works as droits and property). Heirs of playwrights also claimed these non-economic interests in the plays. See, e.g., id. at 222 (reporting an heir's receipt of free tickets for performances of his deceased father's play in 1778).

Professor Gregory Brown likens this sense of droits, perquisites due based on a writer's status as a Comédie-Française playwright, to status-based obligations due under the feudal system. See BROWN, supra note 174 , at 231 . Indeed, he cautions against reading terms like droits-rights and propriété-property with their post-French-Revolution meanings. Id. at 232-33.

230 See RoSE, supra note 111, at 8 ("All forms of property are socially constructed and ... bear in their lineaments the traces of the struggles in which they were fabricated.'); Bracha, supra note 85 , at 241 (stating, in the context of patent law history, that "various societies develop different institutions, which are embedded in and mediated through their peculiar cultural patterns, ideologies and power struggles").
} 
Even before the modern sense of individual rights developed in the late eighteenth century, these playwrights' personal prerogatives were well-known in France. Successful Comédie-Française playwrights were not laboring in obscurity; they mingled with elites and created content for the country's preeminent broadcast medium. People from all walks of life knew how ComédieFrançaise playwrights behaved and expected to be treated. ${ }^{231}$ Ironically, these playwrights' sense of personal prerogatives, as they mimicked the nobility, were precursors of their sense of personal rights that the French Revolution soon engendered.

Over time la proprieté litteraire, thought of as literary propriety-the rules for behaving in a manner becoming to a playwright of the Comédie Françaisecame to be la propriété littéraire, thought of as literary property-interests that the playwrights had, stemming from their work, and which their theater's regulations acknowledged. ${ }^{32}$ Because of the many non-economic factors at play, the box office take often was less important than one of the other prerogatives. ${ }^{233}$ Indeed, one way to prove the ability to run with the social elite was for a playwright to donate his share of the proceeds to a worthy charity, with the need to control his reputation and his play's presentation surpassing the need for income. ${ }^{234}$

231 The "perception of personal comportment, more than any other factor, informed how contemporaries understood what it meant . . to be a dramatic author." BRowN, supra note 174, at 152 .

232 See id. at 208 (stating that for the playwrights, "literary property could not be distinguished from personal propriety"); RosE, supra note 111, at 18 (noting before intellectual property legislation, "it sometimes becomes difficult to distinguish what we might call matters of propriety from matters of property").

The concept of property is, after all, a social statement, seen through a cultural lens. Perceiving something as property, especially an intangible like intellectual property, requires "an act of imagination... People persuade themselves that the things they see can yield the security of entitlement, and then they act... as if the signified entitlements were permanent, solid, objective. And to some degree they are-so long as everyone ... is persuaded." CarOL M. RosE, PROPERTY AND PERSUASION: ESSAYS ON THE HISTORY, THEORY, AND RHETORIC OF OWNERSHIP 294 (1994).

233 See, e.g., BROWN, supra note 174, at 106-08 (reporting a playwright valuing his entrance privileges more); id. at 218 (reporting a playwright valuing free tickets for others more); $i d$. at 109 n.206 (reporting a playwright claiming free tickets as part of his "propriété littéraire' "); $i d$. at 219 (" $[T]$ he playwrights considered such personal recognition a more appropriate justification for remuneration of men of letters than merely payment for intellectual labor performed.").

234 See, e.g., id. at 290-91 (reporting that Beaumarchais donated his part of the box-office take from Le Mariage de Figaro, a considerable sum, to charity). The playwrights "were concerned first and foremost with their ability to control the publication of their work and be recognized for it, rather than to profit from it." Id. at 237. 
There was thus an evidently non-commercial significance to authors of their "property" and of the droits owed them by the Comédie.... [T] he perquisites claimed by authors as property could rarely be reduced to monetary payments, nor could they be alienated from the author's person by the mechanism of the fall [from the performance schedule]. ${ }^{235}$

So, I submit, a direct source of le droit moral was the evolution and application of the detailed rules and regulations for the Comédie-Française playwrights of the ancien regime. Upholding the honor and reputation of a playwright evolved from a major goal regulating his behavior in the social double bind to a personal interest integral to the creative process itself. An aspiring playwright spent long hours controlling the disclosure of a work through the theater's highly regulated process, making sure what was attributed to him properly reflected his creative decisionmaking, and making sure he had input into important changes to the work. These factors all directly had an impact on his honor and reputation, and, thus, his career. A playwright's interest in displaying acceptable behavior evolved into his interest in protecting his own creative decision making processes and the non-economic values of his work, including his public reputation stemming from his work. As he mimicked elites who expressed no particular interest in the economic worth of their own creative work, he learned to value non-economic aspects of his work as well.

In the second half of the eighteenth century, the playwrights also gradually began to appeal to broader public acceptance for their legitimacy. ${ }^{236}$ Relying more on public support and the letter of the regulations, they began to address "the troupe and ... the First Gentlemen, in a new, more legalistic register."237 Some playwrights even filed lawsuits against the acting troupe, but were unsuccessful, essentially due to a lack of jurisdiction. 238 Even while seeking to

\footnotetext{
235 Id. at 219; see also ROSE, supra note 111, at $18 \mathrm{n} .3$ (suggesting that "the author was recognized as an individual with an interest in the status of his name and reputation before he was recognized as a fully empowered figure in the marketplace").

236 See BROWN, supra note 174, at 121-25, 154-58, 191-94 (explaining the growing role of the "patriot" playwright).

237 Id. at 122 . "This new tone, at once less courteous and more legalistic, contrasts strikingly with the language of courtesy used by earlier authors to establish personal relations with the troupe. In many cases in the early 1770 s, the two voices co-existed ...."Id. at 141. After the 1762 revisions to the regulations, the newer playwrights "demanded that the troupe adhere to the regulations in dealing with them, which provided for a more standardized, impersonal functioning of the Comédie." Id. at 140.

238 See id. at 153-54, 158-63, 172-75, 175-77 (reporting actors' unsuccessful efforts to use the law courts to claim a share of a play's proceeds, to seek redress when the troupe dropped a play
} 
address a wider audience ${ }^{239}$ and speak on behalf of the nation, not just the elites, a playwright would speak of his droits d'auteur "in terms of remuneration, control over the staging, and all the marks of honor, such as free entrance privileges."240 These writers already perceived that their creative work entitled them to monetary income, creative control, and honor. The unwritten social rules and written theater regulations under which they operated daily protected both economic and non-economic interests in their work, and in turn the playwrights valued both their economic and non-economic interests in their work. Here is an origin of the protection of non-economic values in French intellectual property law.

\section{THE REVOLUTIONARY STATUTES AND EARLIEST MODERN CASES}

When social upheaval overtook life as it was known in Paris in 1789 , the savvy playwrights, already used to taking pains to position themselves carefully within society, reinvented themselves to survive the French Revolution. ${ }^{241}$ Authority for the theaters and the opera moved from the First Gentlemen to the Paris Commune, the municipal government of Paris, which then had to figure out how to regulate the theaters. ${ }^{242}$ Some previously unsuccessful playwrights seized the opportunity to have their plays performed by the

and barred the playwright from entering the theater, to force the troupe to accept a play, and to claim various forms of mistreatment by the actors).

Despite the law courts' lack of jurisdiction over such matters, plaintiff playwrights knew their mémoires judiciaires-akin to American memoranda of law-could be printed for public reading. These mémoires were a way to criticize the status quo and assert they were writing for the public's benefit as patriots of the nation. Id. at 178 ("The mémoires represented playwrights not as bonnête clients of the court and the royal troupe, but as patriots seeking and deserving autonomy..., so that they could become disinterested spokesmen of, by, and for a socially abstract, morally authoritative, yet politically disenfranchised public.').

239 There were calls for a second national theater, less expensive seats, and a less traditional repertoire. See id. at 182-85.

$240 I d$. at 182 . " $[1] \mathrm{n}$ the 1780 's, . . all of these writers maintained ties to the [royal] court and official institutions of literary life even as they fashioned themselves in print as outsiders and patriots." Id. at 331 .

241 See id. at 414 (referring to these "eighteenth-century writers' great flexibility of selfpresentation" \& "the ability of formerly bonnêtes men of letters to refashion themselves as patriots').

242 Day-to-day control of the Comédie Française was in flux during the 1789-1790 theater season. When the local District Assembly in the theater's district, the Cordeliers, took over, they even threatened guard intervention to force the troupe to perform the play of a playwright who was an assembly member. Id. at 370, 380-82 (explaining the role of the Cordeliers District Assembly and the national guard in the 1789-1790 theater season). The fact that there even was a theater season in Paris in 1789 underscores what an important aspect of French life the Comédie-Française was. Even though it was a high-profile artifact of the ancien régime, the troupe continued performing the works of aspiring - and now revolutionary--playwrights. 
Comédie-Française. ${ }^{243}$ And some Comédie-Française playwrights seized the opportunity to reform the theaters and write actual intellectual property laws.

As prominent men of letters who became members of the District Assemblies in Paris, the Paris Commune, and the National Assembly (the neighborhood, municipal, and national governing bodies, respectively), the playwrights participated in many aspects of reconfiguring the social order of France. With experience working under a detailed regulatory scheme and wellformed ideas about what rules helped writers and what hindered them, Comédie-Française playwrights helped to transform their field. In the first year of the Revolution, the Paris Commune sought information from Beaumarchais on the theater's administration, regulations, and finances, which he reported in a way that made the case for playwrights to receive royalties for all performances of their plays, not just the first run.244 Other playwrights also petitioned the Commune for more control over their plays and the benefits derived from them. ${ }^{245}$

Before municipal legislation could be drafted, however, the playwrights persuaded the National Assembly to address the topic of the theater. Nineteen Comédie-Française playwrights signed a petition proposing new laws for the theater; it was drafted by the playwright Jean-François de la La Harpe and submitted to the National Assembly's Constitution Committee. ${ }^{246}$ In his report as chair of the Constitution Committee, Isaac Le Chapelier agreed with the playwrights and attached a proposed law, incorporating their suggested provisions: ${ }^{247}$ anyone would be able to open a theater, ${ }^{248}$ which would operate

243 See, e.g., id., at 356-61 (describing how, just a few days after the July 14, 1789, storming of the Bastille, Marie-Joseph Chénier interrupted a meeting of the actors to declare that official censorship was over, so his play could now be performed); id. at 370-76 (describing. how he continued to advocate for liberty and his play in the same breath).

244 See id., at 364-66 (explaining Beaumarchais was consulted because he "had greater knowledge of the finances and administration of the royal theater than anyone not in the company or the Ministry of the Royal Household," plus he was a member of the National Assembly, "the best-known" playwright, and the leader of the Société des Auteurs Dramatiques, the Society of Dramatic Authors).

245 See id. at 390, 401-02, 411 (providing examples of playwrights petitioning the Commune about theater rights generally and their plays in particular).

246 See id. at 412-15 (citing M. de la Harpe, Addresse des Auteurs Dramatiques à l'Assemblée nationale [Address of the Dramatic Authors to the national assembly] (Aug. 24, 1790) (trans. the author) \& M. de la Harpe, Discours sur la liberté du Théatre [Speech on the liberty of the Theater] (Dec. 17, 1790) (trans. the author)).

Other playwrights submitted supporting proposals, with differing emphasis. See id. at 414 17 (citing Parisau, Petition des Auteurs Dramatiques Qui n'ont pas signé celle de $M$. de la Harpe Petition of the Dramatic Authors Who did not sign the one by M. de la Harpe] (1790) (trans. the author)).

247 M. Le Chapelier, Rapport fait par M. Le Chapelier, Au Nom du Comité de Constitution, sur la Petition des Auteurs dramatiques [report made by M. Le Chapelier, in the Name of the Constitutional Committee, on the Petition of Dramatic Authors] Jan. 13, 1791) (trans. the author), available at 
under municipal authority.249 No play by a living playwright could be performed without his written consent. ${ }^{250}$ His heirs would own his work for five years after his death. ${ }^{251}$ And then the plays of playwrights dead more than five years would become "public property," or enter the public domain, in today's parlance, for anyone to perform. ${ }^{252}$

Essentially the playwrights had proposed an end to the Comédie-Française's monopoly on its extensive old repertoire and any new plays it would perform in the future. ${ }^{253}$ This proposed legislation stemmed directly from the playwrights' experience operating under the ancien régime regulations for the ComédieFrançaise. Le Chapelier's report referenced specific details of the royal regulations and the problems they caused for the playwrights, such as the way a play became the acting troupe's property after falling from the performance schedule. ${ }^{254}$

http://gallica.bnf.fr/ark:/12148/bpt6k48171h/f1.image.r=.langEN.

248 Id. at 22, art. 1er ("Tout citoyen pourra élever un théatre public...."- "Any citizen will be able to put up a public theater. ..." (trans. the author)).

249 Id. at 23, art. VI (Les entrepreneurs ou les membres des différens theâtres seront, ..., sous linspection des municipalités; ils ne receuront des ordres que des officiers municipaux,...."- "The entrepreneurs or the members of the different theaters will be under the inspection of the municipalities; they will receive orders only from municipal officers, ...." (trans. the author)).

250 Id. at 22, art. III ("Les ouvrages des auteurs vivans ne pourrant être representés sur aucune théatre public,...,sans le consentement formel es par écrit des auteurs,...."- "The works of living authors cannot be performed in any public theater,..., without the formal consent in writing of the authors, ...." (trans. the author)).

251 Id. at 23, art. V ("Les héritiers... des auteurs, seront propriêtaires de leurs ouvrages durant l'espace de cing années aprìs la mort des Auteurs"- "The heirs ... of the authors will be owners of their works for a period of five years after the death of the Authors." (trans. the author)).

252 Id. at 22, art. II ("Les Ouvrages des Auteurs morts depuis cinq ans \&o plus, sont une propriété publique, \&u peuvent, .... être representés sur tous les theattres indistinctement."- "The works of the Authors dead for five or more years are public property, and can,..., be performed in all the theaters indistinctly." (trans. the author)).

${ }^{253}$ The very first line of Le Chapelier's report begins: "Les Auteurs dramatiques demandent la destruction de la privilège exclusif qui place dans la Capitale un Thêatre unique où sont forcés de s'addresser tous ceux qui ont composé des Tragédies ou des Comédies d'un genre élevé..."-" The dramatic Authors ask for the destruction of the exclusive privilege that places in the Capital one sole Theater where all those who have composed Tragedies or Comedies of an elevated type are forced to address themselves...." Id. at 4 (trans. the author); see also Jane Ginsburg, Une Chose Publique'? The Author's Domain and the Public Domain in Early British, French and US Copyright Law, 65 CAMBRIDGE L.J. 636, 654 (2006), available at http://ssm.com/abstract=928648 (stating that "the dramatists' first objective was to destroy the comédiens' exclusivity').

254 See Le Chapelier, supra note 248, at 6 (criticizing the acting troupe for "s'établissant les héritiers privatifs de tous les génies qui ont rendu la France célebre"- "establishing themselves as the private heirs of all the geniuses who made France famous" (trans. the author)); id. at 18 (criticizing the regulation that ensured "toute pièce qui n'aura pas produit 1500 livres de recette en biver, \&o 1000 livres en été, appartiendra aux comédiens"- - "each play that could not produce 1500 livres in receipts in winter, \& 1000 livres in summer, would belong to the comedians"); id. at 19 (listing ways the actors' 
Le Chapelier's report seems to announce the arrival of intellectual property and forecast a legal scheme that could include both economic and noneconomic rights: "The most sacred, the most legitimate, the most unassailable, and ... the most personal of all properties, is the work, [which is] the fruit of a writer's thought; yet it is a property of a type totally different from other properties." 255 Like the droit moral the moral right-this property was in part quite personal. Like the droit patrimonial-the copyright-this property was in part the fruit of labor, à la Locke, but now it was the fruit of the mind's labor. ${ }^{256}$ And it was unlike other types of property. It was literary property; although not yet named as such, it was, indeed, intellectual property.

On January 19, 1791, the National Assembly voted to approve Le Chapelier's proposal, creating a new law that fully incorporated the ComédieFrançaise playwrights' suggestions. 257 And so the first modern French intellectual property statute focused on the theaters and came about due to the efforts of the Comédie-Française playwrights to create theater reforms during the first phase of the French Revolution. 258

Like the playwrights, the new law did not distinguish neatly between any economic and non-economic rights of authors. The requirement of a playwright's written consent to perform his play did not specify what exactly a playwright owned or had a right to, other than the written consent. Depending on market forces and negotiating abilities, a known playwright could now procure a theater contract that included economic and non-economic control over the play. He could control when his work was disclosed to the public, how it was attributed to him, and whether and how it was modified, essentially

ineptitude caused a play to fall from the schedule and a playwright to lose his property, "par un reglement aussi injuste"-_by a regulation so injust" (trans. the author)).

255 Id. at 16 "'La plus sacrée, la plus légitime, la plus inattaquable, et. . . la plus personnelle de toutes les propriêtés, est l'ouvrage, fruit de la pensée d'un écrivain; cependant c'est une propriété d'un genre tout différent des autres propriétés." (trans. the author)). But see Ginsburg, supra note 253, at 654-55 (emphasizing the next lines of Le Chapelier's statement, concerning the public domain); Ginsburg, supra note 172, at 1006-08 (stating that Le Chapelier's main focus was establishing the public domain).

256 Le Chapelier expressed awareness of contemporary English intellectual property concepts. See Le Chapelier, supra note 247, at 4 (referring to "ce qui s'opère en Angleterre..."-"what is taking place in England..." (trans. the author)). For Locke's own view of intellectual property, see Justin Hughes, Locke's 1694 Memorandum (and More Incomplete Copyright Historiographies), 27 CARDOZO ARTS \& ENT. L.J. 555 (2010) (hinting at the equivalent of a right of attribution and right of disclosure).

257 See J.A.L. STERLING, WORLD COPYRIGHT LAW $\ 2.17 \mathrm{C}(i)$, (iii) (3d ed. 2007).

258 In contrast, the very first English intellectual property statute, Statute of Anne, 17108 Ann., c. 19 (Eng.), came about due to disputes within the printing industry. See Liemer, supra note 100, at 9-14.

Mostly due to Beaumarchais's efforts, another law was passed on July 19, 1791, requiring theaters to have agreements with authors before performing plays that had already been printed for sale. See BRowN, supra note 174, at 418 (referring to Beaumarchais's work in this regard). 
exercising the rights of disclosure, attribution, and integrity. But the text of the new law did not actually provide details on any rights other than the formal written consent. Likewise, the new law's provision for ownership by the heirs did not provide any details on what the benefits and burdens of their ownership were. At the time, the details seem to have been presumed to be understood in their historic, cultural context, provided in Le Chapelier's report.

Taken as a whole, the five provisions did give clear protection to the playwrights' economic rights, likely for two reasons. First, the ComédieFrançaise playwrights had been troubled most by the acting troupe's exclusive ownership of a play after it fell from the performance schedule. The remedy for that problem, allowing a writer to maintain ownership after a performance run ended, had the effect of greatly improving the economic benefits for the writer. Note that the new law did not specify this remedy. But the cultural context, the playwrights' proposal, and the reasoning in Le Chapelier's report all made clear that the prominent Comédie-Française playwrights intended to exercise full economic control of their work throughout their lifetimes, and then provide for their heirs for five more years, too. In addition, most of the playwrights read the tea leaves well and avoided aligning themselves too closely in public with the non-economic theater prerogatives that smacked of the excesses of the ancien régime. 259

With the continued involvement of the playwrights and other men of letters, ${ }^{260}$ a broader intellectual property law was enacted in 1793.261 The legislative committee's report, presented by Joseph Lakanal, declared that these legislative provisions would "form...the Declaration of the Rights of Genius."262 The new law extended to all authors the right that the playwrights

\footnotetext{
259 Their proposal carefully aligned their interests with revolutionary interests. See, e.g., Le Chapelier, supra note 247, at 10 (referring to "toutes les pièces, fassent désormais gagner la patrie, en formant meilleurs citoyens" - "all the plays, made henceforth to win the fatherland, by forming better citizens") (trans. the author). Nonetheless, Le Chapelier met his end during the Terror at the guillotine, in 1794. See STERIING, supra note 257, $\$ 2.17$.C(iii) n.38.

260 See Ginsburg, supra note 253, at 18 (summarizing various unsuccessful proposals).

261 Décret de la Convention Nationale, Du dix-neuf Juillet 1793 [Decree of the National Convention, of the nineteenth [of] July 1793], available at http://www.copyrighthistory.org/cgi-bin/kleioc/00 10/exec/showTranscription/\%22f_1793\%22/start/\%22yes\%22 (last visited Sept. 28, 2011). On the unintended disastrous consequences of this new law on the French printing industry, see generally Carla Hesse, The Dilemmas of Republican Publisbing 1793-1799, in PUBLIsHING AND READERSHIP IN REVOLUTIONARY FRANCE AND AMERICA 61-73 (Carol Armbruster ed., 1993).

262 Report of Joseph Lakanal (July 19, 1793), available at http://www.copyrighthistory.org/cgi-b in $/$ kleioc $/ 0010 / \mathrm{exec} /$ showTranscription $/ \% 22 \mathrm{f} \_1793 \% 22 / \mathrm{start} / \% 22 \mathrm{yes} \% 22$. This phrase purposely echoes the title of The Declaration of the Rights of Man (Aug. 26, 1789), available at http:// avalon.law.yale.edu/18th_century/rightsof.asp, which established the French Revolution's founding principles.
} 
had secured for themselves in 1791,263 the right to control the use of their work through their written consent. The 1793 law, however, was both more specific and more broad-ranging. It gave all writers, music composers, painters, and engravers the exclusive lifetime right to sell, authorize the sale of, and distribute their work. It also gave them the right to transfer "the property in whole or in part." 264 And it provided enforcement mechanisms against counterfeit copies made without the author's written consent. ${ }^{265}$ This extension of the playwright's contract right essentially created modern French intellectual property law.

The 1793 law also gave heirs the same rights and property as the authors, for ten years, after which time the works entered the public domain. ${ }^{266}$ In addition, to sue under the statute, writers and engravers were required to deposit two copies of each work at the National Library. ${ }^{267}$

Like the 1791 law, the 1793 law did not provide explicitly for any of the interests protected by le droit moral.268 It too did not define the "property" that authors could transfer and heirs could receive. The 1793 law gave specific economic rights to many authors, such as the exclusive right to sell their work. The right to transfer a work in full or in part even introduced licensing possibilities. But finding protection for non-economic rights there requires imagining the terms of future contracts, just as with the 1791 law.

The laws of 1791 and 1793 were incorporated into Napoleon's Code in 1804,269 and they formed the core of the French intellectual property statutes until 1957. Neither of these Revolution-era laws provided explicitly for the

\footnotetext{
263 See supra pp. 106-07.

264 See supra note 261, at 1, art. 1er ("Les auteurs d'écrits en tout genre, les compositeurs de musique, les peintres et dessinateurs qui feront graver des tableaux et dessins, jouiront, durant leur vie entière du droit exclusif de vendre, faire vendre, distribuer leurs ouvrages..., et d'en céder la propriét' en tout ou en partie."- "The authors of every genre of writing, the composers of music, the painters and draughtsmen who have paintings and drawings engraved, shall enjoy, during their entire life the exclusive right to sell, have sold, [and] distribute their works..., and to transfer the property in whole or in part.") (trans. the author).

265 See id. art. 3 (requiring police to confiscate all copies made without the author's written permission); id. art. 4 (requiring counterfeiters to pay the true owner the cost of 3,000 copies); id. art. 5 (requiring sellers of counterfeit works to pay the true owner the cost of 500 copies).

260 See id. art. 2 ("Leurs béritiers ... jouiront du même droit ... durant l'espace de dix ans, aprìs la mort des auteurs."- "Their heirs ... shall enjoy the same right for a period of ten years, after the death of the authors."); id. art. 7 ("Les béritiers...en auront la propriété exclusive pendant dix années."-"The heirs ... shall have exclusive property in those works for ten years.") (trans. the author).

267 See id. art. 6.

268 See Ginsburg, supra note 172, at 1006 (stating that these "legislative texts reveal a hesitating and uneven progress toward protection of authors' rights"); $i d$. at 1009 (stating the 1793 rhetoric "did not markedly amend the prior reserved characterization of authors' rights").

269 CODE CIVIL (1804) (Fr.).
} 
non-economic interests protected by le droit moral. 270 Indeed, no French statute provided explicitly for le droit moral until 1957.271

In addition, in the aftermath of the Revolution, the French judiciary was careful to distinguish its behavior from the abuses of the judiciary during the ancien régime. ${ }^{272}$ The judge's new role was limited to simply applying the Code, so as not to appear to be making law or ruling arbitrarily. ${ }^{273}$ In this atmosphere, a very literal application of the Code would not necessarily have led to the further development of the non-economic, personal interests in intellectual property protected by le droit moral. But case by case, in judicial decisions, this area of the law did develop in France, ${ }^{274}$ even as the Code continued to not specifically address it.

270 Writing in 1955, a scholar was able to assert accurately, about the statutes, that "[t]he French copyright law, dating in substance from 1791 and 1793, has no provisions on the moral right." Strauss, supra note 15, at 508 n.4; see also STERLING, supra note 257, \$2.17.C(i) (reporting these laws "remained in operation, ..., until the adoption of the Law on Literary and Artistic Property of March 11, 1957').

271 See Rigamonti, supra note 5, at $89 \mathrm{n} .94$ (reporting a proposed statute was rejected in 1908 "'in part because the protection provided by the courts was considered sufficient"); id. at $106 \mathrm{n} .184$ (asserting "French copyright law...[,] based on the revolutionary decrees of 1791 and 1793[,] ... did not have any copyright provision that could have remotely been interpreted as establishing moral rights'); Raymond Sarraute, Current Theory on the Moral Right of Authors and Artists under French Law, 16 AM. J. COMP. L. 465, 465 (1968) ("Unlike the property right, the moral right had at the outset no basis in any code.").

272 See Mitchel de S.-O-l'E. Lasser, Judicial (Self-) Portraits: Judicial Discourse in the French Legal System, 104 YALE L.J. 1325, 1330 (1994-1995) (explaining that before the French Revolution the Parlements, the regional high courts, issued regulations and vetoed royal acts by refusing to record them, abuses of power that helped cause the Revolution).

273 See id. at 1332 ("In the wake of the Revolution, the French attempted to limit judicial power by enforcing a strict separation of powers that asserted absolute legislative supremacy and categorically denied the legitimacy of judicial lawmaking."); see also MERRYMAN \& PÉREZPERDOMO, supra note 30 , at 42 (" $[\mathrm{R}]$ evolutionary ideology assumed that systematic legislation would be clear, complete, and coherent, reducing the function of the judge to one of merely applying the law (i.e., the statute) to the facts.").

The legal fiction of French judges mechanically applying the Code still operates in France. See Lasser, supra note 272, at 1334-43 (describing "the official French portrait of the civil judge"). But French judges actually do consider case precedents, policy arguments, and equity. The process takes place in private, internal court reports and conferences, not in the French courts' brief and formulaic published decisions. See id. at 1343-1409 (describing "the unofficial French portrait of the civil judge"). See also MERRYMAN \& PÉREZ-PERDOMO, supra note 30, at 83 ("Since in all jurisdictions judges are required to decide the cases before them and cannot give up on the ground that the law is unclear, judges continually make law in civil law jurisdictions.").

The lack of public use of precedents is one reason French legal scholars are so influential in French law. See Lasser, supra note 272, at $1403 \mathrm{n} .293$ (referring to "the exalted status of the law professor in the French legal system"). Scholars have greatly influenced perceptions of the origins of le droit moral See STERLING, supra note 257, 2.17.C(iii) (suggesting "[t]he debate continues").

274 See Geller, supra note 69, at 232 (stating that "French judges were pioneers in recognizing 
Early examples include an 1814 case, where a French court found for a writer when a publisher tried to add unauthorized amendments to his text, ${ }^{275}$ effectively protecting the right of integrity. In 1828 , a French court prevented a composer from being forced to publish his music to pay debts, effectively protecting the right of disclosure.276 In 1837 , a collaborator was able to sue successfully for proper attribution. ${ }^{277}$ Other cases at that time addressed whether an author could consent to changes in attribution. ${ }^{278}$ In 1845, the court told a sculptor that "independent of the pecuniary interest, a more precious interest exists for the artist, that of his reputation...."279 After the middle of the nineteenth century, the number of similar cases expanded exponentially. A detailed study of the earliest post-Revolution cases protecting the non-economic interests of authors must await a future article. ${ }^{280}$

How did the courts come to protect these interests in the generations right after the Revolution and the Code put an end to judicial lawmaking? First, I

and protecting such interests"); Sarraute, supra note 271 , at 465 (stating that the moral right "has grown up little by little out of decisions handed down by French courts and tribunals..."); ELIZABETH ADENEy, THE MORAL RightS OF AUTHORS AND PERFORMERS: AN INTERNATIONAL AND COMPARATIVE ANALYSIS 165 (2006) ("It was through judicial elaboration... that this revolutionary law could contribute to the protection of authors' non-economic interests.').

275 See Rigamonti, supra note 5, at 85-86 (quoting, without naming, Billecocq c. Glendaz, Trib. Civ. Seine (Aug. 17, 1814) (" " $\mathrm{A}]$ work sold by an author to a publisher or a bookseller must bear the author's name and must be published as sold or delivered,....'")); see also id. at 86 \& n.78 (referring to strict enforcement of "the default rule against unauthorized modification" by the Trib. Com. Paris in a decision issued Dec. 29, 1842); id. at $\mathbf{n} .76$ (citing a decision of the Trib. Com. Paris, dated Aug. 22, 1845, which protected the integrity of the work in question); ADENEY, supra note 274 , at $54 \mathrm{nn} .73-74$ (referring to French cases protecting the right of integrity in 1804 and 1827).

276 See Rigamonti, supra note 5, at 83 (citing a decision of the Cour royale de Paris, Jan. 11, 1828).

277 Sarraute, supra note 271, at 478 (citing D. Répertoire de Jurisprudence, Vol. Prop. Lit. et Art. no. 194 (Cour d'Appel Paris, Aug. 8, 1837) (" 'TT] he collaborator whose name has been omitted without his knowledge from the title of a work may obtain recognition of his authorship and his rights through the courts.' ')); see also Lavenas c. Renault, Trib. Com. Seine (March 30, 1835) (finding for an artist who brought suit for false attribution); Swack, supra note 5, at $377 \&$ n.110 (citing an attribution decision from the Civ. Trib. Seine issued on March 12, 1836).

278 See Strauss, supra note 15, at 508 n.11 (citing Civ. Trib. Seine, Dec. 17, 1838, Gaz. Trib.); see also Civ. Trib. Seine, Dec. 31, 1845, Huard et Mack, 1362.

279 "IIndépendamment de l'intérét pecuniaire, il existe pour l'artist un intérêt plus précieux, celui de la réputation..." Trib. Corr. [Correctional tribunal], Lyon, 1850, Recueil Périodique et Critique [D.P.] III.14, rev'd, 1852 Paris, Recueil Périodique et Critique [D.P.] II.159 (trans. the author).

280 For a list of the French intellectual property cases decided from 1793 to 1814 , most of which focus on matters other than the non-economic interests protected by le drit moral, see Ginsburg, supra note 172, at 1025-30; see also Calvin D. Peeler, From the Providence of Kings to Copyrighted Things (and French Moral Rights), 9 IND. INT'L \& COMP. L. REv. 423, 437-40, 447-49 (1998-1999) (reviewing some of the early, post-1793, French intellectual property cases); SAUNDERS, supra note 5, at 103-04 (summarizing other early cases). 
would submit that an awareness of the interests protected by le droit moral was already part of the social fabric. The non-economic benefits to a ComedieFrançaise playwright were already a part of people's perceptions of the benefits of being a prominent man of letters, perceptions readily shared by other writers and artists when they all came under the protection of one law in 1793.

Second, for decades after the Revolution, the French standard of living for most people declined dramatically. ${ }^{281}$ While deciding ordinary cases about inheritance, contract, and debt disputes, ${ }^{282}$ the courts seem to have been sensitive to finding ways to help people survive. Authors' widows and children sometimes had little to live on other than the sale of the deceased's manuscript or publishing royalties from his writing. Protecting the honor and reputation of deceased authors, and the practical equivalents of the author's rights of disclosure, attribution, and integrity, was already valued in France. ${ }^{283}$ The courts seem to have just assumed that interests in these rights were among those inherited, among the aspects of the ownership by heirs conferred by the 1791 and 1793 laws.

The language of the day-to-day court decisions does not suggest the courts were doing anything unusual or announcing new concepts. ${ }^{284}$ The 1793 statute gave an author the right to sell, arrange for the sale of, distribute, or transfer his work, throughout his lifetime. Deciding when to sell a work would naturally entail deciding when to disclose it, thus implying the right of disclosure was protected from the outset of the new intellectual property law regime. Negotiating a deal to sell a work likewise would naturally entail specifying details about attributing the work to the author, an interest French writers had

281 See Prager, supra note 63, at 736 (reporting that "the relative industrial strength of France, compared with that of her neighbors, fell to lower levels than under the old regime").

282 See Damich, supro note 5, at 31 n.148 (stating "French jurists were confronted with harmonizing droit moral with the division of community property incident to divorce and with property seized by creditors"); Peeler, supra note 280 , at 432 ("[T] he rights resulted from practical encounters in the courts.").

283 See BROWN, supra note 174, at 203-07 (describing some ad hoc efforts even before the Revolution to help heirs benefit from playwrights' monetary and status-proving draits d'auteur); Peeler, supra note 280, at 432 (explaining how the nineteenth century "proclivity toward protecting more than the economic interests of authors was ... born ... from social concerns about ethics and justice').

284 See Charles A. Marvin, The Author's Status in the United Kingdom and France: Common Law and the Moral Right Doctrine, 20 INT'L \& COMP. L.Q. 675, 684 (1971) ("Implied conditions may be read into the contract to protect the rights of the author.... Legally protected relationships with their contingent rights and duties are thus introduced into the law through judicial legislation of implied contractual conditions.'). A modern French reader still has to look for subtle differences in the language of reported court decisions to see new law evolving. See Lasser, supra note 272, at 1392-1402 (providing the example of a 1982 tort case in which including just two new words in a formulaic decision signaled a change in the law). 
been wrestling to control since the early $1500 \mathrm{~s}$, and an interest protected by the right of attribution. Negotiating a deal under a law that gave the author the right to transfer a work "in whole or in part" also gave the author the right to control characteristics of the work itself, protecting the same interests as the right of integrity. ${ }^{285}$ Indeed, "French Revolutionary concepts embraced links between the ideas of property, liberty and the rights of the person." 286

When court decisions appeared in the early 1800 s talking about artists' noneconomic interests as if they were nothing new, and the advocates referred to these rights in their arguments, ${ }^{287}$ they did not just pluck them out of thin air. They reflected values and concerns ${ }^{288}$ already known in the culture. ${ }^{289}$ The process of the French judiciary strictly applying the new code had to take place within a social context, and deciding cases without ever extending the law was likely always impossible in practice. ${ }^{290}$

\footnotetext{
285 See Damich, supra note 5, at $21 \mathrm{n} .96$ (discussing that "in France, protection of the integrity of a work came out of contract interpretation").

286 STERLING, supra note 257, $\$ 2.17$.C(iii). See also ROSE, supra note 111, at 28 ("The figure of the proprietary author depends on a conception of the individual as essentially independent and creative, a notion incompatible with the ideology of the absolutist state."); Bird, supra note 12 , at 7 (noting the timing correlation of "political revolutions seeking to improve the rights of man" and "the earliest articulations of moral rights law in France").

287 See Sarraute, supra note 271, at 466 (stating that "the real credit for revealing clearly the different aspects of the moral right belongs to the courts, ..., guided by the many brilliant arguments made by attorneys for the state (le ministère public)..." ); Peeler, supra note 280 , at 435 (explaining that the court decisions repeated the parties' arguments).

288 Geller, supra note 69, at 232 (stating that French judges, "confronted with the facts, ... found equitable solutions' in the case law, out of which grew the moral rights to control the disclosure of works, to obtain the attribution of authorship, and to maintain the integrity of works'). A judge's sense of the appropriate equitable solution would naturally be informed by the values and concerns of his culture and his time. See Peeler, supra note 280, at 435 (stating that in intellectual property disputes, the courts were "mirroring the same concerns reflected in nineteenth century French society').

289 See Peeler, supra note 280 , at 434 (referring to "the socio-political influences on the judiciary"); SAUNDERS, supra note 5, at 105 (stating that "the droit moral is the artifact of a specific legal-cultural environment"); BROWN, supra note 174, at 425 (noting "how much continuity there was in literary life from ... the mid-seventeenth-century to the ... late eighteenth and nineteenth centuries'); Prager, supra note 34, at 140 (noting that establishing intellectual property systems "required mainly the public approval of intellectual property").
}

290 See Lasser, supra note 272, at 1346, citing 1 JEAN CARBONNIER, DroIT CIVIL 35-36 (1967): 'Quite often, contrary to the classic syllogism where they should descend from the legal rule to the concrete decision, [judges] start by positing the concrete decision that strikes them as humanly desirable, and then endeavor to work back to a legal rule. Things must always have happened this way since ... there have always been judges, and judges who think.' 


\section{CONCLUSION}

The French courts continued developing this area of the law, applying the underlying concepts case by case, in many otherwise ordinary legal disputes. By the time German philosophers were developing concepts of personal rights, which previous scholars have pointed to as required underpinnings of le droit moral,291 the French courts already had experience applying le droit moral concepts, extending their reach and further developing them. Early nineteenth century French courts applied the not-yet-named ${ }^{292}$ droit moral protections in ordinary legal disputes over intellectual property. The timeline simply does not work when scholars insist that le droit moral needed the work of late nineteenth and early twentieth century German philosophers and French legal scholars. More likely, the scholars needed post hoc justifications.

Recall that ancient Roman authors credited the divine for their work. Medieval and Renaissance authors relied on the good graces of wealthy patrons. And the Comédie-Française playwrights behaved like the nobility to find success. Perhaps it is not entirely ironic to find origins of democratizing laws like le droit moral in such rarified support. As le droit moral protects the personal, non-economic interests of the author, it recognizes that each unique creation process parallels human concepts of the divine, whether ancient or modern. ${ }^{293}$ Le droit moral also recognizes that societal support encourages the creative process and enriches the society, much as the support of wealthy Renaissance patrons encouraged the creative process and enriched the patrons' lives. And like the ancien régime playwrights who found recognition and personal dignity within their society by behaving as nobles, le droit moral recognizes the personal dignity and ennobling aspirations of all authors.

As for the larger lesson learned, the drama of social and legal change is itself a compelling story. The most dramatic public manifestations of regime change, like the storming of the Bastille on July 14, 1789, are easy to document and memorialize. The prerequisite experiences and tipping points in the daily lives of individuals, however, are more subtle and harder to pinpoint. And the process of building new aspects of a society, including its laws, takes time, for a

\footnotetext{
291 See Rigamonti, supra at 5, at 370 (explaining that le droit moral was derived from German philosophy).

292 Most frequently, the credit for naming le droit moral goes to André Morillot, who used the term in his article, $D e$ la personnalité du droit de publication qui appartient à un auteur vivant, REvUE CrITIQue Legislattve 29 (1872), cited in Jean-Luc Piotraut, An Authors' Rights-Based Copyright Law: The Faimess and Morality of French and American Law Compared, 24 CARDOZO ARTS \& ENT. L.J. 549, 595 n.363 (2006).

293 See Roberta Rosenthall Kwall, Inspiration and Innovation: The Intrinsic Dimension of the Artistic Soul, 81 NOTRE DAME L. REV. 1945, 1946-82 (2006) (describing connections between art, theology, and moral rights).
} 
new normal to evolve. But new ways of life rarely spring suddenly and fully formed and distinct from the old ways, even after the type of full-scale destruction wrought by the French Revolution. The groundwork for new ways of configuring society, new ways to conceptualize property, new ways to legislate for intellectual property, started long before the old ways were abandoned.

Both technological and social revolutions impacted the development of France's intellectual property laws. With each change, the issues, concerns, and very human reactions of authors were remarkably similar to the issues, concerns, and personal reactions that authors wrestle with today. Someone created something. And then they wanted to derive fair income from their work, protect its original form, and protect their connection to it. Figuring out how to do so inevitably turned them-and returns us-to core concepts of property and individual rights.

"Times are never so unlike that we may ignore the past in attempting to understand the present." 294 Today literary, visual, and performing artists struggle to assert their rights while using new technology, just like the early French writers in print did. Present day legislatures struggle to draft effective intellectual property legislation for our wireless internet society, much like the Comédie-Française playwrights did once untethered from royal oversight. We can take heart that we likely already have had the experiences that will guide us, just as they already had the necessary experiences to draw on as they created modern French intellectual property law. While we cannot have perfect hindsight for our own time, many of the necessary components to meet our own intellectual property challenges are already in place and others are about to develop.

294 Dent, supra note 87, at 1; see also Jennifer S. Light, New Technologies and Regulation: Why the Future Needs Historians, 2001 L. REV. M.S.U.-D.C.L. 241 (explaining that "history has a way of repeating itself'). 